\title{
Rendvédelmi testületek a polgári magyar állam időszakában 1867-1919
}

A polgári magyar állam 1867-1945-ig tartó időszaka magában foglalja a történelmi Magyarország utolsó periódusát azaz a dualizmus idejét és a trianoni békediktátum által megcsonkított Magyarország történetének kezdeti időszakát, a két világháború közti Magyar Királyság idejét. Ez alatt a 78 év alatt a magyar rendvédelemben ugyan történtek változások, a struktúra azonban alapjaiban változatlan maradt, leszámítva az 1918-1919-es forradalmat, illetve a nyilas diktatúra terror alakulatait, bár ezen diktatúrák nem tekinthetők a polgári magyar államfejlődés részének.

A kiegyezéstől a II. világháborúig terjedően tehát alapvetően azonosnak tekinthető a magyar állam rendvédelmi struktúrája, bár ezen időszak alatt is számos módosításra került sor. Egymást követően csaknem 20 - a központi államhatalomnak közvetlenül alárendelt — rendvédelmi testület müködött Magyarországon. Emellett tevékenykedtek 1919-ig — a magyarországi rendőrségek államosításáig — az önkormányzatok rendörségei is. (I.sz. melléklet)

\section{A dualizmuskori magyar rendvédelem alkotta azt a szilárd alapot, amelyre a két világháború közötti rendvédelem építkezhetett}

A dualizmuskori magyar rendvédelmi rendszeren belül a derékhadat nyilvánvalóan a csendőrség alkotta, melyet a rendőrségek, illetve — az 1919. évi államosítás nyomán — a magyar rendőrség követett. A magyar rendvédelem harmadik legerősebb pillérét pedig kétség kívül a határőrizetet ellátó testületek képezték. A magyar társadalom, az ország és a külső körülmények is dinamikus változásokon estek át 1867-1919-ig. Ezt a folyamatot követte a magyar rendvédelem is.

A kiegyezési törvény értelmében a rendvédelmi feladatkörök egyértelmüen a társországok hatáskörébe kerültek. A neoabszolutizmus időszakában a rendvédelmi testületek centrális vezetés alatt álltak, és az egész birodalomra kiterjedően, egységesen müködtek. A magyarországi rendvédelem újjászervezése szempontjából a HABSBURG-erőszakszervezetek két lényeges vonással rendelkeztek. Egyrészt a kor színvonalán álló, kiváló hatásfokkal müködő testületek voltak. Másrészt viszont a császári elnyomás eszközeiként kivívták a lakosság gyülöletét. A kiegyezés után tehát a magyar rendvédelem újjászervezésekor nem kerülhetett sor e testületek átvételére, különösen a rendőrség és a csendőrség esetében, amelyek jeleskedtek a hazafiak üldözésében. ${ }^{1}$

Az alkotmányosság helyreállításakor, 1861 októberében visszaállt az eredeti magyar állapot, amely szerint a rendvédelmi testületek alapvetően az önkormányzatokhoz tartoztak, illetve azok részét képezték. Modernizációjukra a kiegyezés után, egy lassúbb folyamat nyomán került sor, amely bizonyos centralizációs elemeket is tartalmazott. ${ }^{2}$

A Wiener Zeitung-ban 1860. X. 21-én megjelent deklarációjában a császár kinyilatkoztatta, hogy megosztja a hatalmat a tartománygyülésekkel és a birodalmi tanáccsal. A magyarországi rendvédelmi testületek esetében ez azt jelentette, hogy az önkormányzati rendörségek újra kezdhették müködésüket. A császár azonban a birodalom egésze számára rendelt központi hatóságként továbbra is fenntartotta a „KK Oberste Polizei Behörde"-t. ${ }^{3}$

Ezzel Magyarországon végképp megszünt az 1852. IV. 25-én legfelsőbb elhatározással az egész birodalomra kiterjedő hatáskörrel létrehozott császári rendőrség. ${ }^{4}$

Fennmaradt azonban a Császári Királyi Csendőrség, melyet a kiegyezés nyomán oszlattak fel Magyarországon, Erdély és Horvátország kivételével. A fennmaradó két csendőrezredet 1876-ban a közös hadsereg területileg illetékes hadtest-parancsnokságainak felügyelete alól az Erdélyre és Horvátországra kiterjedő müködési területtel rendelkező honvéd kerület-parancsnokságok felügyelete alá helyezték, majd 1881-ben beolvasztották a felállításra kerülő Magyar Királyi Csendőrségbe. ${ }^{5}$

A magyarországi rendörségek a kiegyezés nyomán továbbra is az önkormányzat részeként müködtek. Olyan mértékben voltak egységesek, illetve tértek el egymástól, amilyen mértékben érvényesültek az önkormányzatok sajátosságai. Minden önkormányzatnak joga volt hatósági területén saját rendőrséget fenntartani. A vidék közbiztonságában azonban a császári zsandárság kivonásával rohamos romlás állt be, amelyet a vármegyei rendörségek képtelenek voltak feltartóztatni. A Magyar Királyságban az önkormányzati rendőrségi modell — a törvényhatósági jogú városok kivételével — az 1870-es években megbukott. E modell müködtetésének utolsó kétségbe esett kísérlete a királyi biztosok kiküldése volt. Ennek keretében egy-egy különösen rossz közbiztonsági helyzettel rendelkező vármegyecsoport élére teljhatalommal felruházott királyi biztost neveztek ki. Ilyen volt RÁDAY Gedeon, akit a dél-alföldi vármegyecsoport élére neveztek ki. RÁDAY Gedeon ugyan drákói szigorral néhány év alatt rendet teremtett, azonban küldetése lejártával az anarchia rövid időn belül visszarendeződött. Szükség volt tehát egy olyan rendvédelmi testületre, amely vidéken tartósan képes fenntartani a rendet. Ezt a 
szervezetet a kortársak a csendőrségben találták meg. Végül 1881-ben — vidékre kiterjedő müködési területtel - létrehozták a Magyar Királyi Csendőrséget, mint országos rendvédelmi szervezetet, korabeli szóhasználattal élve: közbiztonsági őrtestületet. ${ }^{6}$

A rendörségeket a közigazgatás sajátos szakközegeinek tekintették. Az önkormányzati rendörségeket rendőrtisztviselők irányították, ők voltak a mai rendőrtiszti kar korabeli megfelelői. Velük szemben ugyanazok a képesítési követelmények érvényesültek, mint a közigazgatás más területein dolgozó tisztviselőkkel szemben. ${ }^{7}$

A rendezett tanácsú városokban a mindenkori rendőrkapitány is tagja volt a képviselőtestület határozatait és a törvényhatóság rendeleteit végrehajtó elöljáróságnak. ${ }^{8}$

A rendörtisztek kinevezésére, illetve választására ugyanazok az elöírások vonatkoztak, mint a közigazgatási tisztviselőkére. Ettől a 1886-tól kezdve tértek, amikortól a városi kapitányokat a föispánok nevezték ki. A kinevezés ilyen módon a kormány befolyása alá került. Minden egyéb tekintetben azonban a rendőrségek az önkormányzatok kompetenciájában maradtak. ${ }^{9}$

A dualista Magyarország rendőrségei két nagy csoportra oszthatók: az állami és az önkormányzati rendőrségekre. Állami rendőrség csupán három működött: a Budapest Magyar Királyi Fővárosi Állami Rendőrség, amelyet 1872-ben ideiglenes, majd 1881-ben végleges jelleggel államosítottak Fővárosi Rendőrség néven. ${ }^{10}$ A másik két rendőrség, a fiumei és a Magyar Királyi Határrendőrség létrehozása a határörizettel volt kapcsolatos. ${ }^{11}$

Az önkormányzati rendőrségek három csoportot alkottak: a nagyközségek, a rendezett tanácsú és a törvényhatósági jogú városok rendőrségeit. Nem volt két egyforma rendőrség Magyarországon, bár bizonyos közös vonások régiónként, önkormányzati típusonként érzékelhetőek voltak. Végül is a magyarországi rendőrségeknek a Magyar Királyság viszonylag homogén gazdasága, kulturális légköre, a társadalmi alapok azonossága egységes közeget teremtett, amely hatással volt szervezetükre is.

A nagyközségek jelentős része nem élt azzal a lehetőséggel, hogy saját rendőrséget müködtethet. Az önkormányzati rendőrségek fenntartását ugyanis az önkormányzatoknak kellett finanszírozniuk. A községek egy része nem tudta vállalni a fenntartás anyagi terheit. Csupán néhány gazdagabb község rendelkezett rendőrséggel. E rendőrségek általában egy őrs nagyságúak voltak, létszámuk többnyire 620 fő között mozgott. A községi rendőrségek számára a mintát, a legközelebbi városi rendőrség jelentette, még az egyenruhájuk szabásában is ezt a példát követték. Szinte természetes volt, hogy a csupán ritkán előforduló nagyobb bünügyek kivizsgálására is ezt a városi rendőrséget kérték fel. ${ }^{12}$

A törvényhatósági jogú és a rendezett tanácsú városok rendőrségei között is jelentős különbségek voltak, ezek a testületek azonban már képesek voltak önálló rendőri szervezetként müködni.

Mivel az önkormányzatokban a virilizmus elve érvényesült, az önkormányzat alárendeltségébe tartozó rendőrségre is azoknak volt a legnagyobb befolyásuk, akik a legnagyobb adót fizették.

Bár az önkormányzati rendőrségek alapvető tulajdonsága az egyediségük volt, bizonyos közös vonások a szervezetükben is fellelhetők. A városi rendőrségek legfelsőbb szervezeti egysége a rendőrkapitányi hivatal volt, amelynek élén a rendőrkapitány állt. A hivatal általában több osztályból állt, a leggyakoribb az igazgatásrendészeti feladatokat ellátó közigazgatási, a bünesetek kivizsgálásával foglalkozó bünügyi, a közrendvédelmi teendőket végző rendőrbejelentő és rendörkapitánysági vagy örtestületi, valamint az iparügyi osztály volt. A kapitánysági hivatalhoz tartozott még általában a fogda, a számvevőség, mely a gazdálkodást végezte továbbá a segédhivatal, és végül a kézbesítők és a szolgaszemélyzet (a fütők, takarítók stb.). A rendőrlegénység döntő többsége az örszobákon teljesített szolgálatot. A kisebb városokban a rendőrkapitányi hivatal nem oszlott osztályokra, és az őrszobai rendszer is hiányzott. ${ }^{13}$

Az önkormányzati rendörségek precíz feltérképezése Magyarországon ma csak részlegesen végezhető el. A rendőrségekre vonatkozóan ugyanis nem készültek az egész országra kiterjedő statisztikák. A századfordulón ugyan kísérletet tettek arra, hogy könyv formájában mutassák be a magyarországi rendőrségeket, ez a vállalkozás azonban csak részben sikerült, mert nem mindenhonnan futottak be a kért adatok. A nagyközségi és városi rendőrségek egy részének létszámát ma már csak az elcsatolt területek fennmaradt levéltári anyagainak feltárása útján lehetne hitelesen megállapítani. A városi rendörségek létszáma azonban az ismert városi rendőrségi adatok alapján megbecsülhető. A Magyar Királyságban 24 törvényhatósági jogú és 106 rendezett tanácsú várost számolva területükön — a közigazgatási területrendezést megelőzően - 2252912 ember élt. A térségben mintegy 12000 fönyi rendőr teljesíthetett szolgálatot, nem számolva a számvevőség és az egyéb szervezeti háttéregységek személyzetét. ${ }^{14}$

A rendőrtisztviselők (tisztek) és a rendőrség személyi állományának más csoportjai között hozzávetőlegesen 1:20 volt az arány. A detektívek ekkor még kevesen voltak, és nem tartoztak a tiszti kar- 
hoz. Ezeket az állománycsoportokat először a fővárosi rendőrségnél rendszeresítették, majd a nagyobb vidéki városokban. A magyarországi rendőrségeknél elterjedt a detektívek alkalmazása, külön „detektívtestületet” alkottak, függetlenül attól, hogy a kapitányság mely osztályára, milyen ügy kivizsgálására voltak beosztva. A legtöbb detektív természetesen a bünügyi osztályokon dolgozott. Külön fönökük is volt a rendörségeken belül: a detektívfönök. ${ }^{15}$

A XIX. század végétől előtérbe került a magyarországi rendőrségek államosításának a témája. A vélemények azonban megoszlottak, és az államosítás tartalmáról is különböző elképzelések éltek. Az államosítás lényege az volt, hogy a rendőrségek a Magyar Királyi Belügyminisztérium közvetlen irányítása alá kerüljenek. Arra vonatkozóan, hogy az önkormányzatok milyen súllyal vehetnek részt a helyi rendőrség irányításában, az elképzelések eltérőek voltak. Az államosítás kezdeményezői és szószólói maguk is rendőrök voltak. Az állami rendőrségek ugyanis elit rendőrség jelleggel müködtek, jobb volt a kiképzésük, a felszerelésük, a fizetésük. Az állami rendvédelmi testületek tagjai nyugdíjképesek voltak, míg az önkormányzati rendőrtisztviselöket - az önkormányzati tisztviselök többi tagjával megegyezően - 6 évre választották. Az önkormányzatok sem léptek fel a települési rendörségek államosításának elgondolása ellen, hiszen az államosítástól hatékonyabb helyi rendőrséget vártak, amelynek kiadásai ráadásul nem a városi költségvetést terhelik.

A vidéki rendőrségek államosításának kérdésében a Magyar Rendőrtisztviselők Országos Egyesülete (MROE) bizonyult az egyik legaktívabb fórumnak. HEGEDÜS Sándor marosvásárhelyi városi rendőrkapitány 1893-ban kongresszust szervezett a rendőrségek államosítása témájával. A kongreszszus memorandumot fogadott el, melyet a miniszterelnökhöz, a belügyminiszterhez és a képviselőház elnökéhez juttattak el. A rendőrségek államosításának témája mozgalom élén HEGEDÜS András és dr. ANGYAL Ármond a MROE elnöke álltak. Gróf TISZA István miniszterelnök, aki ebben az időben belügyminiszter is volt, 1905 januári miskolci beszédében a vidéki rendőrségek államosítása mellett foglalt állást. A miniszterelnök beszéde bátorítólag hatott az államosítás híveire. A MROE pályázatot hirdetett e témában, amelyet dr. MISKOLCZY László rendőrtisztviselőnek ,A vidéki rendőrség államositása" címü munkája nyert meg. A müvet az egyesület 1909-ben nyomtatásban is megjelentette, és küldöttsége átadta a belügyminiszternek. Dr. PEKÁRY Ferenc - aki 1902-ben Londonban töltötte a szabadságát és saját ötletétől vezérelve tanulmányozta az újjlenyomat-rendszert, majd hazatérve mint a fővárosi rendőrség kerületi kapitányi tisztséget betöltő tisztviselöje eredményesen kezdeményezte az újjlenyomat-rendszer hazai bevezetését - miniszteri tanácsos vezetésével új osztályt hoztak létre a Magyar Királyi Belügyminisztériumban a vidéki rendőrségek államosításának előkészítésére. ${ }^{16}$

Dr. PEKÁRY Ferenc 1914 tavaszára készült el javaslatával. Az országot 11 rendőrkapitányságra osztó elképzelése azonban nem talált osztatlan helyeslésre. A világháború kitörésével a téma lekerült a napirendről. WEKERLE Sándor, a belügyi tárca vezetését is ellátó miniszterelnök 1918. VII. 9-én — a háború miatt megromlott közbiztonság javítása érdekében — törvényjavaslatot nyújtott be Magyar Királyi Állami Rendőrség létrehozására vonatkozóan, az Osztrák-Magyar Monarchia végnapjaiban azonban e téma tárgyalására érdemben már nem kerülhetett sor.

A dualizmus időszakában végül is nem valósult meg a magyarországi rendörségek államosítása. $\mathrm{Az}$ állami rendőrségek között is a fővárosi rendőrség volt a legtekintélyesebb. A budapesti állami rendőrség - a rendőri felügyelet szempontjából a csatolt községek területét is figyelembe véve - 42 309 holdon, azaz 24348 hektáron müködött. Ily módon a 2073 főnyi rendőri őrszemélyzetre (közbiztonsági, járör állomány) fejenként 20 hold körüli terület jutott, természetesen a belterületek javára differenciáltan. A székesföváros lakossága a csatolt községekkel együtt csaknem 1000000 föt tett ki. Ez a létszám azonban gyakorlatilag nagyobb volt, hiszen a főváros agglomerációjába tartozó települések lakosságának jelentős része nap-mint-nap megfordult Budapesten. A fővárosi rendőrség létszáma hozzávetőlegesen a törzslakosság 0,2 \%-át tette ki. Ezekből az adatokból azonban nem szabad túlzott következtetést levonni, hiszen a korabeli jogrend és a lakosság erkölcsi felfogása is jelentősen különbözött a maitól. Ennek ellenére is megállapítható azonban, hogy a rendörök nem maradtak munka nélkül. A rendőri szolgálat kimerítőnek bizonyult, előfordult, hogy a tiszti kar jelentős része a hivatalos órák letelte után, késő estig dolgozott. A rendőrök között sokan kaptak idegkimerülést, amit az elöljárók a sokszor napokig tartó és pihenéssel alig félbeszakított, kimerítő szolgálattal magyaráztak. Az államrendőrségi kórház rendőri osztályán évente mintegy félezer rendőrt ápoltak. Pedig a rendőrség személyi állományán belül a korosztályok egészséges arányban voltak képviselve. Az 1900-as évek elején a tisztikar $16 \%$-a 20 év, $35 \%$-a 10 év, $49 \%$-a pedig 10 éven aluli szolgálati viszonnyal rendelkezett. Az örszemélyzetnél ez úgy alakult, hogy mintegy 100 fö rendelkezett 20 év feletti, csaknem 150 fö 1520 év közötti, közel 600 fő pedig 10-15 év közötti szolgálati viszonnyal. A fennmaradó kb. 1200 rendör szolgálati viszonya még ennél is kevesebb volt. ${ }^{17}$ 
A fővárosi rendőrség személyi állománya több csoportra oszlott. A tisztviselői kar legfelső rétegét a fogalmazó karbeliek alkották, mintegy 100 fövel. Utánuk következtek az orvosok 28 fö, majd a csapattisztek 24 fö, végül pedig a számvevőségi, a pénztár és a kezelö tisztek 103 fö. A csapattisztek az őrszolgálati állomány parancsnokai voltak. Számukra az állami iskolai végzettségi követelmény csupán az érettségi volt, szemben a fogalmazó karbeliekkel, ahol a képesítési követélményt minimum a jogakadémiai végzettség jelentette. A rendőrségen belül háttérintézmény jelleggel funkcionáló szervezeti egységek tisztviselői részére az állami iskolai végzettség minimuma a polgári volt. A legénységnek elemi iskolai végzettséggel kellett rendelkeznie. A detektíveknél előnyben részesítették az érettségizetteket, de polgári iskolai végzettséggel is be lehetett jutni a detektívek közé. Figyelemre méltó azonban az örszemélyzet idegennyelv-tudása. Csaknem 350 fö tudott németül, mintegy 250 valamilyen szláv nyelven, 150 fő románul, közel 50 fő pedig más nyelveken beszélt. Az őrszemélyzet állományából gyakorlatilag minden harmadik ember beszélt valamilyen idegen nyelven.

A rendőrség személyi állományába történő felvételek során nem alkalmaztak prekoncepciós diszkriminációt. A meghatározó a szakmai rátermettség, az iskolai végzettség volt, felekezeti szempontok nem érvényesültek. 1907-ben például az őrszemélyzetnél 20 izraelita és 36 görögkeleti vallású rendőr is dolgozott. A rendőrlegénység túlnyomó többsége, 1561 fö a katonaságnál altiszti rangot viselt. A rendőri örszemélyzet döntő többségének eredeti foglalkozása földműves volt, de más foglalkozási ágak képviselői is megtalálhatók voltak a rendőrség soraiban: iparos 459 fö, kereskedő 42 fö, szellemi foglalkozású 29 fö. ${ }^{18}$

A fővárosi rendőrségnél összesen 2690 fö dolgozott. Ebbe a létszámba beletartoztak még a detektívek (polgári biztosok) és a csaknem 250 fónyi díjnok és egyéb alkalmazott. A detektívek nyomozati munkát végeztek, a vizsgálati tevékenységet azonban már a fogalmazói karhoz tartozók látták el.

A budapesti rendőrség élén az elnöki osztály állt, amely a fökapitány közvetlen alárendeltségébe tartozott. Az elnöki osztályhoz tartoztak az államrendészeti ügyek, a gazdasági ügyek, a titkári hivatal, amely a személyi ügyekkel és a fegyelmi eljárásokkal, valamint a rendőrség lapjának szerkesztésével foglalkozott. Ide tartoztak még a kihágási ügyek és a sajtóiroda. A közigazgatási ügyosztályon az útlevél-, a közlekedési-, az erkölcsi-, az engedélyügyekkel-, a talált tárgyakkal és vegyes közigazgatási ügyekkel foglalkoztak. A bünügyi osztály is szakosodott: emberélet elleni, betörési, zsarolási, lopási, zsebtolvajlási, sikkasztási részlegekre oszlott. A budapesti rendőrség szervezeti egysége volt még a fogház- és tolonc ügyosztály, a rendőr-orvosi hivatal, a számvevőség, a pénztár, a bejelentési és központi kézbesítő hivatal, a kerületi kapitányságok és a csatolt területek kapitányságai, a dunai felügyelőség, a rendőr-föparancsnokság és a vasúti kirendeltségek. A rendőr-föparancsnokság irányítása alá tartozott a tartalékosztály és a lovasosztály, valamint az örszobák. A főváros területén az örszobák száma mintegy 90 volt. $^{19}$

A budapesti rendörség egyes részlegei országos hatáskörrel müködtek. A bünügyi nyilvántartást a rendőrtisztviselők magán feljegyzéseiböl hozták létre. A hivatal felállítását 1897-ben rendelték el. A budapesti anyag fokozatosan bővült a vidéki rendőrségek információival. Az Országos Bünügyi Nyilvántartó Hivatal 1909. I. 1-jén kezdte el müködését. ${ }^{20}$

A Bűnügyi Múzeum is a fővárosi rendőrség gondozásában jött létre 1908-ban. A múzeum megteremtéséhez a feltételeket az igazságügyminiszteri rendelet teremtette meg, amely elrendelte, hogy az eljárás befejezését követően a tanulmányi célra alkalmas bünjeleket az ügyészségek küldjék meg a fövárosi fökapitányi hivatalnak. ${ }^{21} \mathrm{~A}$ fövárosi rendőrség szolgálatellátásának az eredményességét nem csupán a szervezeti felépítés és a felszereltség volt hivatott biztosítani. A legfontosabbnak a személyi állományt tekintették. Ebből fakadóan magas mércét állítottak a testületi tagok elé fizikai, szellemi és pszichológiai, valamint erkölcsi tekintetben egyaránt. Ezzel párhuzamosan azonban a személyi állomány minden tagjának biztosította a foglalkoztató a társadalmi állásához méltó életvitelhez szükséges feltételeket, még az özvegyek számára is. Ezen feltételek egyik legfontosabb eleme volt a fizetés.

Ahogy a rendőr ellenőr esetében a legénységnél is alkalmazták a címzetes címet, ugyanúgy éltek e formával a tisztviselői karban is. A címzetes cím azt jelentette, hogy a rendőr tisztviselő a rangsor következő fokozatába tartozó címet használhatta, de a hozzá tartozó beosztásba még nem nevezték ki. A magasabb beosztások megüresedése esetén azonban azon „címzetes” címet viselők közül választottak ki az elöléptetendő személyt, aki a leghosszabb ideje rendelkezett a magasabb beosztás betöltéséhez elöírt képesítési követelményekkel. Címzetes címet adományoztak olyan tisztviselőknek is, akik ugyan iskolai végzettségük miatt nem kerülhettek a magasabb tisztviselői karba és annak megfelelő fizetéssel járó beosztásba, de a hivatali főnökségük ezzel ismerte el több évtizedes kifogástalan munkájukat. A tisztviselői karokban a kezdő hivatalnokok általában fizetés nélküli beosztást, illetve rangot kaptak. Ez azt jelentette, hogy munkakörük ugyan megfelelt a címüknek, de mindaddig csak az alacsonyabb 
tisztviselői kar fizetésében részesülhettek, amíg a címüknek megfelelö állás meg nem üresedett, vagy a beosztások számát nem növelték. Ezt a szisztémát a tisztviselői kar valamennyi rétegénél alkalmazták. $^{22}$ (II.sz. melléklet)

A dualizmus időszakában fejlődtek ki a nemzeti alapokon nyugvó és modern értelemben is rendőri szervezetnek minősülő testületek. Szakítottak az osztrák titkosrendőri hagyományokkal. ${ }^{23}$ A rendőrségek nyíltan müködtek - ez nem jelentette a bünügyi operatív munka eszközeinek mellőzését — és az önkormányzati felügyelet demokratikus kontrollt biztosított felettük.

A Magyar Királyságban működő rendőrségek nem különültek el a közigazgatástól, hanem annak integráns és egyben speciális részét is alkották. A neoabszolutizmus osztrák rendőrségétől abban is eltértek, hogy beépültek a közigazgatásba. ${ }^{24}$

A dualizmus elő évtizedében keletkeztek azok a tapasztalatok, amelyek - a polgári fejlődés eredményeként, a Kárpát-medencei specifikumokat is figyelembe véve és a nyugat-európai tapasztalatokat hasznosítva - a kor színvonalán álló, ugyanakkor sajátosan magyar rendőrséget eredményeztek. A rendörségre, mint a közigazgatás részére hatással volt a közigazgatás centralizációja. A dualizmusban azonban, bár erre kísérlet történt, nem választották le a rendőrségeket a közigazgatásról. Csupán néhány exponált helyen került a rendőrség közvetlen állami ellenőrzés alá: a fövárosban és a határterületeken, ahol eleve állami rendőrségként jött létre a Magyar Királyi Határrendőrség. ${ }^{25}$

A magyar határörizeti szervezetek még jelentősebb fejlődésen mentek keresztül, mint a rendőrségek, bár a határórizet vezető testülete is rendörség volt, a Magyar Királyi Határrendőrség. A magyar határőrizetben több államigazgatási szervezet, testület vett részt. A kiegyezés után elsőként a Magyar Királyi Pénzügyőrség kapcsolódott be a határőrizetbe. ${ }^{26}$

A Magyar Királyi Pénzügyőrség az osztrák Finanzwache helyébe lépett, az osztrák szakmai örökséget továbbfejlesztve. ${ }^{27}$

A Magyar Királyi Pénzügyőrség szervezeti felépítése négy lépcsős volt, a minisztériumi és a pénzügyigazgatósági vezető szervezeteket is figyelembe véve. ${ }^{28}$ A pénzügyőrség szakaszonként volt tervezve, élén egy szemlész vagy fövigyázó állt.

Több szakasz alkotta a pénzügyőri biztosi kerületet, melyet egy biztos vagy biztoshelyettes teljes felelősséggel vezetett. Egy-egy pénzügyigazgatóság területén több biztosi kerület lehetett és a pénzügyigazgatóságnál, mint pénzügyi eladót, főbiztosként, esetleg pénzügyőri felügyelőként osztottak be, az utóbbi felügyeleti joga több vármegyére is kiterjedt.

A pénzügyőrség felügyeletét a Magyar Királyi Pénzügyminisztérium központi fogalmazó személyzetéhez tartozó központi felügyelök gyakorolták.

Szolgálati és személyes ügyekben a vármegyék pénzügyőr alakulatai egyébként közvetlenül a vármegyénként szervezett pénzügyigazgatóság alárendeltségébe tartoztak. ${ }^{29}$

A pénzügyigazgatóságok kebelében müködtek a pénzügyi biztosok, akik egy-egy biztosi területet irányítottak. Egy pénzügyigazgatóság hatósági területén több biztosi kerület müködött, ezek pedig szakaszokra oszlottak. A biztosi kerületek és szakaszok száma a pénzügyigazgatóság területének nagyságától, valamint az ott müködő ipari és kereskedelmi intézmények számától és méretétől függően változott. A pénzügyőrség legénységi állománya a szakaszok müködési területén helyezkedett el. Szervezeti egysége a szakasz volt. A szakasz élén álló szemlész vagy fövigyázó szállását a szakasz müködési területének közepén jelölték ki, amely egyben a szakaszparancsnokság állomáshelye is volt, valamint a legénység elhelyezését is itt biztosították. ${ }^{30}$

A pénzügyörség egyenruhás, fegyveres testület volt. Személyzete két állománykategóriából állt, a legénységből és a tisztekből. A tisztikart a biztosok és föbiztosok, valamint a felügyelők és a föfelügyelők alkották, a legénységhez pedig a vigyázok, a fővigyázók és a szemlészek tartoztak. ${ }^{31}$

A legénységi állományba jelentkezőket vigyázói rendfokozattal vették fel. A vigyázókat fövigyázóvá, majd szemlésszé - a tiszti rendfokozattal bíró szolgálati elöljárójuk javaslatára — több éves eredményes szolgálati munka után lehetett előléptetni, amennyiben a pénzügyigazgatóságok által szervezett minősítő vizsgán megfeleltek. A bíráló bizottság tagjai pénzügyőrtisztek, a pénzügyigazgatóság fogalmazói karának tagjai voltak. ${ }^{32}$

1911-ig a pénzügyőrség legénysége a szolgálat ellátásához szükséges tudnivalókat a próbaidő alatt, az idősebb, több évtizedes tapasztalattal rendelkező vigyázóktól, fővigyázóktól és szemlészektől tanulta el, a munka végzésé során. 1911-ben azonban a pénzügyminisztérium egy központi újonc iskolát állított fel. Ezt követően hat hónapi kiképzés után kerültek a pénzügyőrök szolgálati helyükre, vigyázói rangban. ${ }^{33}$

A központi újonc iskolára — és korábban közvetlenül a végrehajtó szolgálatba — kerülök részére felvételi követelmény volt: 
" - a magyar szent korona országaiban polgárjoggal;

- erös, teljes ép testalkattal bírnak;

- nőtlenek vagy gyermektelen özvegyek;

- 18 éven felül, de 30 éven alul vannak.

Azokat, kik aktív katonai szolgálatból közvetlenül vagy elbocsátásuk után legföllebb egy év alatt lépnek, a pénzügyörségbe 35 éves korukig is fel lehet venni.

A felveendőnek magyarul olvasni, írni és a számolás elemeit tudni kell. Akik az országban divatozó több nyelvet értik, elsőbbséggel bírnak. Szükség esetén azonban a pénzügyigazgatóság vehet fel olyanokat is, kik írni és olvasni nem tudnak, de ezek száma a pénzügyigazgatóság területén rendszeresített pénzügyörségi vigyázok számának hatod részét nem haladhatja meg.

A felveendő előbbi életmódját és magaviseletét igazolni tartozik. ${ }^{34}$

A tiszti állományba tisztviselőnek jelentkezőknek érettségivel kellett rendelkezniük, és kinevezésüket megelőzően általában az illetékes pénzügyigazgatóságon, mint fogalmazó gyakornokok dolgoztak. A vigyázókat, a fővigyázókat és a szemlészeket a pénzügyigazgatóságok vezetői, a biztosokat és a föbiztosokat, valamint a felügyelőket a pénzügyminiszter, a föfelügyelőket pedig az uralkodó nevezte ki. A XX. század első évtizedében a pénzügyőrség 5121 főnyi legénységet 270 tiszt irányította. A határörizeti feladatokat 549 fö végezte. ${ }^{35}$

A vámhivatalokat a kiegyezést követően az új magyar pénzügyminisztérium is az osztrák birodalmi pénzügyminisztériumtól vette át. Kezdetben az osztrák gyakorlatnak megfelelöen a vámhivatalok az adóhivatalokkal voltak egyesítve, fokozatosan választották szét őket. Az 1880-as években kialakult a dualista Magyarország vámhivatalainak rendszere, amelyen a későbbiek során már nem hajtottak végre alapvető változtatásokat. ${ }^{36}$

A vámhivatalok fö- és mellékvámhivatalokra oszlottak. Mindkét kategóriában megkülönböztettek első- és másodosztályú vámhivatalokat. A mellékvámhivatalok csak a határvonalon, a fővámhivatalok pedig a vámvonalon és a vámterületen, azaz az ország belsejében is felállíthatok voltak. Fö- és mellékvámhivatalok, ezen belül az elsö- és másodosztályú vámhivatalok áruelvámolási hatáskörükben különböztek egymástól. A legkiterjedtebb hatáskörrel az elsőosztályú fővámhivatal rendelkezett. ${ }^{37}$ (III.sz. melléklet)

A vámhivatalok alárendeltségében müködtek az úgynevezett bemondóőrsök. Ilyeneket ott létesítettek, ahol a vámhivatalok nem közvetlenül a határ mellett müködtek. Értesítö- vagy bemondóállomásnak is nevezték őket. Feladatuk az volt, hogy a határon beérkező árut számba vegyék és az illetékes vámhivatalhoz irányítsák, illetve értesítsék a hivatalt az áru érkezéséről, így csak azok jelentkeztek a vámhivataloknál vámkezelésre, akiknek áruja vámköteles volt. ${ }^{38}$

Sem a bemondóőrsök, sem a különbözö rangú vámhivatalok nem rendelkeztek külön fegyveres örszemélyzettel. A területileg illetékes pénzügyigazgatóság valamely pénzügyör biztosi kerületéről rendeltek ki a vámhivatalokhoz pénzügyőröket. A kirendelés időtartama alatt a pénzügyőrök a vámhivatalnokok alárendeltségébe kerültek. ${ }^{39}$

A vámhivatalok annak a pénzügyigazgatóságnak voltak alárendelve, amelynek a müködési területén az állomáshelyük volt, szakmailag azonban a fövámigazgató alárendeltségébe tartoztak, akit a pénzügyminiszter tanácsosi címmel ruházott fel. ${ }^{40}$

Vámügyekben egy országos szintű tanács is müködött: az úgynevezett Vámügyi Tanács, amelyet az 1890. IV. 11-ei minisztertanácsi határozat alapján hoztak létre. ${ }^{41}$

A vámvizsgálatot vámhivatalnokok végezték. Vámhivatalnoki gyakornok jelöltnek azt vették fel, aki érettségi vizsgával rendelkezett, a gyakornoki kinevezésére a gyakornoki vizsga letétele után kerülhetett sor, majd a fövámhivataloknál vagy a pénzügyigazgatóságoknál letett, szakvizsga után lehetett belöle segédtiszt. A magasabb vámtiszti rangra történő kinevezésnek újabb szakmai vizsga volt az előfeltétele, amelynek birtokában a vámtiszt már mellékvámhivatali vezető lehetett. A fővámhivatali vezetői beosztáshoz szükséges szakmai vizsgát csak a budapesti, a zágrábi vagy a fiumei vámhivataloknál lehetett letenni. A vizsgáztatok között itt szakértők is voltak, például gyógyszerészek, nagy áruismerettel rendelkező kereskedők stb. A vámhivataloknál a tisztviselők gyakornoki, segédtiszti és fövámtiszti rangban vámszedő, ellenőr, pénztáros, raktárgondnoki és vámhivatalvezetői beosztásokat töltöttek be. ${ }^{42}$

A dualista Magyarország területén 19 pénzügyigazgatóság alárendeltségében 24 fö- és 28 mellékvámhivatal müködött. A budapesti fỏvámhivatal — a fóvámigazgató személyén keresztül — közvetlenül a pénzügyminisztériumnak volt alárendelve. Az 52 vámhivatalban közel 300 hivatalnok végezte munkáját, közel kétharmaduk a fơvámhivatalokban, egyharmaduk pedig a mellékvámhivatalokban. ${ }^{43}$

A Magyar Királyi Csendőrség 1891-től vett részt a határőrizetben, esetenként azonban már koráb- 
ban is bevonták a határőrizeti feladatok ellátásába. Ilyen volt például 1884-ben a romániai marhavész és kolerajárvány idején a határ lezárása, amiben a Magyar Királyi Csendőrségen kívül a Magyar Királyi Honvédség alakulatai is részt vettek.

A határszéli csendörség kialakulása a magyar-román határegyezményhez vezethető vissza. Az előkészületi munkákat követően a magyar-román határt 1887. XII. 7-én, illetve november 25-én kelt nemzetközi egyezménybe foglalták, melyet a magyar országgyülés 1888. IV. 30-án emelt törvényeröre. $^{44}$

Az eredményesebb határőrizet kialakítását szolgálta az 1891. VII. 15-én kelt belügyminiszteri rendelet. Ennek első paragrafusa rendelte el a határszéli csendőrség felállítását. ${ }^{45}$ A határszéli csendőrséget az erdélyi, kolozsvári székhelyü csendőrkerület kebelében hozták létre, amelynek személyi állománya akkor 985 föt tett ki. A határszéli csendőrség szervezeti egységeinek müködési területét, a székhelyeket honvédelmi és belügyminisztériumi közös bizottság tervezte meg. Az átszervezés során döntően határőrizeti feladatok ellátására létrehoztak egy új szárnyat két szakasszal és 17 őrssel, három tiszttel és 66 főnyi legénységgel. Az új határszéli csendőri erők 1891 júliusában kezdték el szolgálatukat. $^{46}$

A századelőn átszervezték a Magyar Királyi Csendőrséget, ennek keretében 9 csendőrkerület felállítását tervezték. Ekkor alakították ki a nagyszebeni csendőrkerületet, amelynek elsődleges feladata a határ őrizete volt. A román határ mentén a csendőr őrsök számát 17-ről 21-re, a személyi állományt pedig 66-ról 117-re emelték. ${ }^{47}$

A határszéli csendőrség 1912-ben nyerte el végleges szervezetét és létszámát. OLÁH Ödön csendőr ezredes vezetésével három fös bizottságot küldtek tanulmányútra az osztrák örökös tartományokba és Bosznia-Hercegovinába az ottani csendőrség határőrizeti feladatainak tanulmányozása céljából. A bizottság által tapasztaltak felhasználásával alakították ki a határszéli csendőrség struktúráját. ${ }^{48}$

A határszéli csendőrség 1912. évi átszervezése során a magyar-szerb határon a szegedi csendőr kerület alárendeltségébe tartozó csendőr őrsök számát 42-röl 52-re, a határőrizeti teendőket ellátó csendőrségi személyi állomány létszámát pedig 149röl 310 főre, a nagyszebeni csendőr kerületnél az őrsök számát 107-re, a határőrizeti teendőket ellátó csendőrök létszámát 723 före emelték. ${ }^{49}$

Mindkét csendőr kerület struktúrájába olyan speciális szervezeti elemeket is iktattak, amelyek csupán a határszéli csendőrségnél kerültek bevezetésre. Kikülönített törzstiszteket neveztek ki, akik a csendőr kerületen belül több szárny határörizeti munkáját fogták össze. A kikülönített törzstisztek parancsnokságai az érintett hatósági területen müködtek. A csendőr kerület-parancsnokságokon egyben egy törzstiszt a határörizeti szakreferensi munkakört is ellátta. A kikülönített törzstisztek az ő vezetésük alá kerültek.

A határszéli csendőrség másik speciális elemét a nyári őrsök rendszere alkotta. A határszéli őrsök müködési területén néhány fö elhelyezésére alkalmas kisebb objektumokat hoztak létre, amelyeket csak nyáron használtak, amikor az anya-őrs személyi állományának egy része települt ide. Télire az épületeket bezárták. Fenntartásuk lényege az volt, hogy szemmel lehessen tartani a határon átvezető olyan ösvényeket a Kárpátok bércei között, amelyek elsősorban nyáron voltak járhatók. ${ }^{50}$

1912-ben a Magyar Királyi Csendőrség a horvát-szlavon csendőrség személyi állománya nélkül 12507 főt számlált; ebből 1357 látott el határőrizeti szolgálatot. A Magyar Királyi Csendőrségnek a határ mellett szolgálatot teljesítő része nem részesült speciális határőrizeti képzésben, a csendőrség szolgálati szabályzata azonban tartalmazta a határőrizeti feladatokat, és azokra a csendőri szolgálatra való felkészítés során mindenkit kioktattak, a határszéli csendőrök számára pedig továbbképzést tartottak. A határszéli szolgálat nehézségeit azzal kompenzálták, hogy a határszéli csendőrök az illetményeik felett 40 fillér pótlékban részesültek.

A Magyar Királyi Határrendőrség a pénzügyi szervek és a határszéli csendőrség mellett részt vett a magyar határörizetben, mint annak vezető testülete. A határrendőrségről szóló törvényt 1903-ban elfogadták ugyan, de a müködését csak 1906. I. 15-én kezdte meg, az 1905. XII. 9-ei minisztertanácsi határozat alapján. ${ }^{51}$

Kezdetben 11 határrendőr kapitányság alárendeltségében 24 határrendőr kirendeltség funkcionáltt, ${ }^{52}$ 1908-tól 1912-ig a kirendeltségek irányítása alatt határrendőri örségek is müködtek. A dualizmus korának végére a kapitányságok száma 17-re, a kirendeltségeké pedig 14-re emelkedett. A Magyar Királyi Határrendőrség létszáma is gyarapodott, a kezdeti 160 főről a történelmi Magyarország fennállásáig 624 före. A határrendőrség irányítását a belügyi tárca határrendőri osztálya végezte. ${ }^{53}$ (IV.sz. melléklet)

A határrendőrség személyzete négy csoportra oszlott: az intézkedő, a végrehajtó, a kezelő és végül a szolga személyzetre. Az intézkedő személyzethez a fogalmazói kar tartozott, a végrehajtó személy- 
zetet a felügyelők, a polgári biztosok és a biztosok alkották. A kezelő személyzetbe az írnokokat, a hivatali tiszteket, a segédtiszteket, a napidíjasokat, a szolga-személyzetbe pedig a napibéreseket és a hivatalszolgákat sorolták. ${ }^{54}$

A mai tiszti rendfokozatnak a fogalmazó karon belüli címek feleltek meg. A legalacsonyabb rendfokozatú a fogalmazó-gyakornok volt, őt követte a segédfogalmazó és a fogalmazó, s végül a föfogalmazó. A kirendeltségek élén általában a föfogalmazók álltak. A határrendőrség tiszti karán belül törzstiszti jellegü rangjuk volt a határrendőr kapitányoknak és tanácsosoknak. A határrendőrség teljes személyi állományát a belügyminiszter nevezte ki. Kivételt képeztek a kulcsfontosságú határrendőr kapitányi és a belügyminisztériumban szolgálatot teljesítő tanácsosi beosztásúak, akiknek kinevezéséhez uralkodói jóváhagyás is szükséges volt. ${ }^{55}$

Az egész határrendőrség szolgálati teendőit a határrendőr tanácsosok irányították. A kapitányság törvényes müködéséért a határrendőr kapitány volt felelös, ő állapította meg a kapitányság valamennyi beosztottjának a munkakörét, ö engedélyezte a kapitányságon belüli áthelyezést. A kapitányságok közötti áthelyezések esetében a belügyminiszter jóváhagyása volt szükséges. A fogalmazói személyzet általában irodai munkát végzett, szervezett, irányított a kapitány utasítása szerint, közvetlenül a kirendeltségvezető, illetve a kapitányság vezetőjének alárendeltségében. A nyomozásokat és az útlevelek kezelését a felügyelők végezték, őket a detektív felügyelő irányította. Az oktató-felügyelő végezte a fogalmazói karon kívüli állomány folyamatos képzését. A polgári biztosok a határrendőr kapitányság határszakaszának egy-egy részéért voltak felelősek. Mivel egy före több 10 km-nyi határszakasz jutott, munkájukat csak a helyi csendőri erők bevonásával tudták elvégezni, felhasználva a helyi lakosok közül is azokat, akik némi díjazás ellenében adatokat szolgáltattak a tudomásukra jutott tiltott határátlépésekről. A kapitányságokon a hivatalvezető közvetlen vezetésével végezték az irodai munkát a hivataltisztek, a hivatali segédtisztek és az írnokok. A kapitánysági hivatal vezetője alá tartoztak a kézbesítéseket ellátó altisztek. A határrendőr biztosok sorompóőrként, a kijelölt helyiség előtti őrszemként, a toloncok és a letartóztatottak kíséröjeként, a foglyok őrzőjeként, a magasabb rangú határrendőrök szolgálati tevékenységének fegyveres biztosítójaként végezték feladataikat, kisebb irodai munkákat látták el, kivételes esetekben kézbesítettek is. A szolgaszemélyzet végezte a kétkezi munkát, például takarított. ${ }^{56}$ (V.sz. melléklet)

A korabeli képesítési követelmény a határrendőr kapitányok részére a jogi diploma birtoklását írta elő. A határrendőrség tisztikarának Ludovika Akadémia-i, vagy jogakadémiai végzettséggel kellett rendelkeznie. A felügyelőktől az úgynevezett főgimnázium vagy fő reáliskola, illetve az ezekkel a középiskolákkal egyenrangú kereskedelmi iskola, vagy katonai iskola elvégzését követelték meg. ${ }^{57}$

A határrendőrség legénységi állományába való felvételhez a követelmények között első helyen állt a magyar állampolgárság és a feddhetetlen előélet, valamint a magyar nyelv ismerete szóban és írásban. Követelmény volt még legalább 6 év katonai vagy csendőri, illetve együttes szolgálat, az egészséges testalkat, a 40 év alatti életkor és a rendezett anyagi viszonyok. Elönyben részesítették azokat a pályázókat, akik a magyar nyelven kívül valamelyik nemzetiség nyelvét is beszélték. A határrendőrséghez pályázókat próbaidőre vették fel, ennek eredményes leszolgálása után véglegesítették őket. A próbaidős határrendöröket először három hónapig tartó tanfolyamra vezényelték, ahol a határrendőri szolgálathoz szükséges elméleti ismereteket sajátították el. ${ }^{58}$

A határrendőr kapitányságoknak speciális részét képezte az egészségügyi szolgálat. A balkáni rendkívül rossz egészségügyi helyzet következményeként az 1890-as évek végén és az 1900-as évek elején több ízben is behurcolták Magyarországra a kolerát. Mivel ebben az időben az egészségügy irányítása a Magyar Királyi Belügyminisztérium hatáskörébe tartozott, a belügyminiszter 1911. IV. 27-én kelt körrendeletében elrendelte a határállomásokon a kötelező orvosi vizsgálatot. A vizsgáló állomások élén orvosok álltak, akiknek joguk volt a veszedelmes fertőző betegség gyanújába került utasokat feltartóztatni és karanténba helyezni. Munkájukhoz a megfelelő hatósági támogatást, a melléjük beosztott határrendőrbiztos és határrendőrök, illetve csendőrök nyújtották. ${ }^{59}$ A vizsgáló állomásokat ellátták:

- ápolóval, fertötlenítővel,

- helyiségekkel, amelyekben az orvosi vizsgálat, a gyanús betegek elkülönítetten való megfigyelése és ápolása, továbbá személyi és tárgyi fertőtlenítés foganatosítható legyen,

- betegszállító eszközökkel,

- fertőtlenítő készülékekkel és szerekkel.

A vizsgáló állomást egészségügyi szempontból a törvényhatósági tiszti főorvos, eljárási vonatkozásban pedig az illetékes járási föszolgabíró ellenörizte. ${ }^{60}$

A dualizmusban a polgári fejlődés útjára lépett Magyar Királyság államigazgatásának részeként kiépültek és megerősödtek a rendőri és határőrizeti testületek. E szervezetek nyugat-európai tapaszta- 
latokat is hasznosítottak, ugyanakkor a magyarországi sajátosságoknak is megfeleltek. A testületek viszonylag kis létszámmal, de eredményesen müködtek. A rendőrségek közvetlen felügyelete megoszlott az önkormányzat és a kormány között, a határőrizeti szervezetek viszont egyértelmüen a kormány irányítása alatt álltak.

A Magyar Királyi Csendörség alkotta a dualizmuskori magyar rendvédelem fö pillérét. Hatósági területe kiterjedt - a törvényhatósági jogú városok kivételével — az egész országra, e területen élt a lakosság túlnyomó többsége. ${ }^{61}$ Lehetőség nyílt 1882-től arra is, hogy a törvényhatósági jogú városok kérésére - térítés ellenében - a Magyar Királyi Csendőrség alakulatai e településeken is bekapcsolódjanak a rend fenntartásába. A törvényhatósági jogú városok jelentős része élt is ezzel a lehetőséggel különösen a külterületek tekintetében. ${ }^{62}$

A csendőrség intézménye hosszú és eredményes utat tett meg addig, amíg eljutott a Kárpátmedencébe. A testület francia eredetü. Eredetileg nem belső rendfenntartó erőként müködött, hanem a hadsereg része volt. Először VII. Károly uralkodása idején találkozunk a csendőrséggel. Az 14201436-ig tartó angol-francia háború idején 1429-ben a francia király önkéntes lovagokból és toborzott zsoldosokból egy állandó jellegü hadsereget szervezett, melyet nem csak az angol haderö, hanem a belső ellenfelei megfékezésére is bevetett. Ezt a haderöt nevezték - a hübéri hadseregtől történő megkülönböztetéseként - „gens d' armes”-nek, azaz fegyveres embernek. A nagy francia forradalom idején a „gens d' armes” csapatokat már katonai rendőrségként alkalmazták. Ebből a fegyvernemből szervezte meg 1779-ben I. Napóleon császár a közbiztonsági katonai őrtestületét, melynek elnevezése a „gens d' armes” maradt. A hadsereg kötelékében szolgálatot teljesítő csendőrség eredetileg lovas alakulat volt. A rendfenntartási feladatokra rendelt csendőrség már gyalogosokból és lovasokból állt. Szervezése azonban a kor lovassági katonai szervezetére hasonlított legjobban. A XIX. sz. elején a francia csendőrség ezredekből, az ezredek osztályokból, az osztályok szárnyakból, a szárnyak pedig szakaszokból álltak. A csendőrség kisebb egysége a „brigádé” volt. A legénységet háborúviselt, kipróbált katonákból állították össze. ${ }^{63}$

A csendőrség intézményét francia mintára a napóleoni császárság vonzáskörébe tartozó itáliai és németalföldi államok is átvették. Így jött létre a csendőrség Lombardiában is. 1815-re Lombardia ismét osztrák fennhatóság alá került. A HABSBURGok a lombardiai csendőr ezredet nem oszlatták fel, hanem eredeti funkciójának megfelelően alkalmazták. A lombardiai csendőr ezred legénysége olasz volt, így a vezényleti nyelvet németre változtatták ugyan, de a belszolgálati és igazgatási nyelv 1850ig olasz maradt. Az ezred elnevezése „Kaiserliche und Königliche Lombardisches Gens d' armeria Regiment"-re változott. Ekkor az ezred személyi állományának $2 / 5$ része gyalogosokból, $3 / 5$ része lovasokból állt, a müködési területe pedig Dél-Tirolra is kiterjedt. Az ezred öt századra, a századok két szárnyra, a szárnyak két szakaszra oszlottak. Háború esetén a lombardiai csendőrség — ezzel a szervezéssel - a hadsereg kötelékében rendfenntartási feladatokat látott el. Békeidőben a szakaszok őrsökre tagozódtak és közbiztonsági szolgálatot teljesítettek. Az ezred létszáma 1012 fö volt. A szolgálati időt 16 évben állapították meg, melyből az első három év próbaszolgálatot jelentett. ${ }^{64}$

Az 1848-1849-es szabadságharc leverése után a HABSBURGok az önkényuralmi rendszerre tértek át az egész birodalomban. Ebbe az új államigazgatási struktúrába kiválóan illett a csendőrség intézménye. Alexander BACH osztrák belügyminiszter javaslata alapján először Magyarországon 1849. augusztusában pozsonyi székhellyel, majd 1850. I. 6-án győri székhellyel állítottak fel csendőr ezredeket. A Monarchia többi részén 1850 tavaszán kezdték meg a csendőrség szervezését. Elöször 16 ezredet hoztak létre, majd 1854-ben még három ezredet szerveztek, melyek közül kettőt Magyarországon létesítettek. Így az öt kormányzói kerületre osztott Kárpát-medence valamennyi kerületére jutott egy csendőr kerület. A csendőrség birodalmi felügyelője Johann Franz KEMPEN von Fichtenstamm altábornagy volt, aki egyben — az 1852 és 1859 között müködő — Legfelsőbb Rendőrhatóság irányítását is ellátta. A Legfelsőbb Rendőrhatóság a birodalmi rendőrség és a birodalmi csendőrség közös föparancsnokságaként müködött. A csendőrség humán tekintetben a hadügyminisztérium alárendeltségébe tartozott, 1859 után pedig a szolgálati ügyeket illetően a HABSBURG-birodalom rendfenntartásért felelös tárcájának az irányítása alatt is állt. A neoabszolutizmus csendörségének szervezése 1853-ban fejeződött be, ekkor a csendőrség kötelékében 18647 fö teljesített szolgálatot. ${ }^{65}$

1860-ban a csendőrség létszámát csökkentették. 10 ezredet hoztak létre 7923 fővel. A birodalmi csendőrséget a lombardiai csendőr ezred állománya részesítette kiképzésben. A csendőr legénységet a hadsereg katonái közül válogatták ki. A katonai zsoldnál jóval magasabb illetményt kaptak, szolgálati idejük 8 év volt. A csendőrség intézménye a tömegek szemében a neoabszolutizmusnak talán a legellenszenvesebb szervezete volt. A hazafiak üldözésének elsődleges végrehajtása mellett beleszólt a lakosság magyaros öltözködésébe, szakáll viseletébe is. A magas fogdai díjak arra ösztönözték a csend- 
őrség tagjait, hogy a fogdák mindig tele legyenek. ${ }^{\mathbf{6}}$

A kiegyezéskor a HABSBURG csendőrség magyarországi ezredeit felszámolták. Erdélyben és Horvátországban azonban tovább müködtek csendőr ezredek Császári és Királyi Csendőr Parancsnokságok néven. A szolgálati nyelv a német maradt. A magyar kormánynak sikerült elérnie, hogy az uralkodó 1876. III. 17-ei leiratában elrendelte, hogy a horvátországi és erdélyi csendőr ezredeket a birodalmi hadügyminisztériumtól a magyar kormány 1876 . V. 1-től vegye át. ${ }^{67}$

1876. IV. 24-én az 15521.eln.sz. honvédelmi miniszteri rendelettel módosították a csendőrség egyenruháját, a legénység kiegészítése vonatkozásában nem tértek el az 1876-ot megelőző állapottól. A csendőr-parancsnokságokat a területileg illetékes honvéd kerületi-parancsnokságok közvetlen alárendeltségébe helyezték. A szolgálati időt három évre leszállították. Honvéd tiszteknek az erdélyi és horvátországi csendőrséghez próbaszolgálatra történő beosztását a honvédelmi miniszter engedélyezte. A legénység zsoldja évi 400-600 korona között mozgott a rendfokozattól és beosztástól függően. ${ }^{68}$

$\mathrm{Az}$ erdélyi, illetve horvátországi csendőrség szervezete ekkor négy lépcsős volt. Az országos csendör-parancsnokság (Lands Gens d' armerie - Regiment) szárnyakra (Flüggel), a szárnyak szakaszokra (Zug), a szakaszok őrsökre (Posten) oszlottak. A magyar kormány által 1876-ben átvett két csendőr kerület létszáma 1301 fỏ volt. Erdélyben 15 tiszt vezényletével 792 főnyi legénység, HorvátSzlavón országban pedig 11 tiszt parancsnoksága alatt 483 fönyi legénység látott el szolgálatot. ${ }^{69}$

A kiegyezési törvényben foglaltaknak megfelelően a történelmi Magyarországnak Erdély és Horvátország nélküli részén az 1867. V. 23-i rendelet szüntette meg a csendőrséget. A kiegyezést követöen a vármegyékben visszaállították a pandúr intézményt. A pandúr kifejezés még Mária Terézia korából ered, ekkor felállítottak egy portyázó rendfenntartó ezredet, melyet pandúr ezrednek neveztek. Az egységet később a határőrvidéki ezredekbe olvasztották be. A legénység egy részét azonban a határörvidékkel szomszédos vármegyékben rendőrként alkalmazták, nevüket pedig továbbra is megtartották. A kiegyezést követően a vármegyék rendfenntartói szempontból csendbiztosi kerületekre oszlottak, élükön a csendbiztos állt. Öket a főispán nevezte ki. A csendbiztosok irányításával látták el szolgálatukat a pandúrok, akiket az alispán vagy a szolgabíró nevezett ki. A rendfenntartás hagyományosan a vármegyék belügyének számított. A rendőri szervezet, a müködési szabályok vármegyénként változtak. A legénységet rosszul fizették, írni, olvasni alig tudtak. ${ }^{70}$

Az egész országra kiterjedő csendőrségi intézmény kialakítását 1880-ban kezdték el, de már nem a HABSBURG-ház, hanem a magyar uralkodó osztály fennhatósága alatt. 1880. novemberében SzENDE Béla honvédelmi miniszter benyújtotta a képviselő háznak a Magyar Királyi Csendőrség legénységi állományának kiegészítéséről, TISZA Kálmán miniszterelnök — egyben belügyminiszter — pedig a közbiztonsági szolgálat szervezéséről szóló törvényjavaslatát. Ez utóbbi a Magyar Királyi Csendőrségnek az egész ország területén történő megszervezéséröl szólt. ${ }^{71}$

A Magyar Királyi Csendőrség felállítása szervesen illeszkedett a polgárságnak és a nagybirtokos arisztokráciának a kiegyezés utáni államigazgatás kiépítésére vonatkozó elképzeléseibe. Ezen társadalmi erők centrális közigazgatást kívántak létrehozni. Ezzel szemben a gentry réteg a megyei önállóság megőrzésében látta hatalmi pozícióinak védelmét Az érdekellentétek tükröződtek a képviselőházi vitában is, mely a csendőrségi törvényjavaslatok szavazásakor alakult ki. Több irányból támadták a Magyar Királyi Csendőrség felállítását elrendelő törvényjavaslatot. ORBÁN Balázs kifejtette azirányú aggodalmát, hogy a karhatalom a kormány támasza lesz a választásoknál. SZEDERKÉNYI Nándor képviselő a karhatalomnak a polgári kormány kezéből történő kiengedését bírálta. Volt aki, mint IRÁNYI Dániel ,a törvényhatóságok önkormányzati jogának fenntartása alapján” új tervezetet akart készíttetni a belügyminiszterrel a leendő karhatalom felállítására vonatkozóan. Voltak olyanok is, mint MOCSÁRY Lajos, akik a megyék eddigi közbiztonsági szervezetét kívánták újjászervezni. A törvényjavaslatot végül — két napi vita után — lényegében eredeti formájában fogadta el a képviselőház. ${ }^{72}$ Az 1881/II. és az 1881/III. tc.-t az uralkodó 1881. II. 14-én szentesítette. ${ }^{73}$

A vármegyék ezzel elvesztették karhatalmukat. A pandúrszervezet megszünt. A Magyar Királyi Csendőrség létrehozását szükségessé tette a csendbiztosi rendszer rossz hatásfokú bünüldöző tevékenysége. A társadalmi fejlódéssel - a kor technikai vívmányainak alkalmazásával a termelésben és az élet más területein - valamint a közlekedés rohamos változásával a bünözés is módosult. A polgári fejlődés útjára lépett ország kormányának szüksége volt a Magyar Szent Korona alá tartozó területekre kiterjedő - centrális vezetés alatt álló — rendvédelmi szervezetre. A Magyar Királyi Csendőrség személyi és fegyelmi vonatkozásban a honvédelmi miniszter, szolgálati tekintetben pedig a belügyminiszter alá tartozott. ${ }^{74}$ A Magyar Királyi Csendőrség szervezeti felépítése megegyezett az erdélyi csendőrség szervezetével. 1884-ben a csendőrség már az egész ország területén müködött. Ekkor 6 kerületre, 23 szárnyra, 55 szakaszra és 882 örsre oszlott, a létszám pedig 115 tiszt és 5052 főnyi legény- 
ség volt. ${ }^{75}$ A Magyar Királyi Csendőrség legénységi állományát a hadseregben szolgálatot teljesítő katonák köréből választották ki önkéntes jelentkezés alapján. A Magyar Királyi Csendőrség felállításakor a tisztikart részben honvédségi tisztekből, részben pedig volt csendbiztosoknak a föispánok által kiválogatott és javasolt tagjaiból állították össze. A volt csendbiztosok szakmai képzése céljából a Ludovika Akadémián több turnusban tanfolyamot indítottak. Az altisztek kiképzése céljából Déván a csendőrség teljes kiépítéséig - altiszti iskolát hoztak létre. ${ }^{76}$

A Magyar Királyi Csendőrség szolgálatát a felállítását elrendelő 1881. évi törvényekben foglaltak alapján látta el. A törvény azonban csupán a testületre vonatkozott és nem annak a müködésére. Ebből fakad, hogy vannak, akik úgy értékelik a helyzetet — nyilvánvalóan felületes ismereteik miatt mintha a testület tevékenysége szabályozatlan lett volna, illetve müködésük nem az országgyülés által létrehozott törvények, hanem csupán az irányító tárca elvárásai szabályozták volna. Ez a téveszme akarva-akaratlanul azt sugallja mintha a testület tevékenységét nem jogszabályokban rögzítették volna, hanem az utasításokban foglaltak határozták volna meg. Ez a sugallat azonban nem felel meg a valóságnak. A dualizmuskori Magyar Királyságban ugyanis a magyar rendvédelem tevékenységeit nem egy-egy testületre vonatkozóan szabályozták. Magát a tevékenységet szabályozták függetlenül attól, hogy azt mely szervezet hajtotta végre. A téveszmét hangoztatók tehát félremagyarázzák a történelmi valóságot azáltal, hogy a jelenlegi helyzetet vetítik vissza a dualizmus korára, azokat a megoldásokat keresve a XIX. század végén és a XX. század elején, amelyek napjainkat jellemzik. Amennyiben pedig ilyennel nem találkoznak különböző jelzőkkel igyekeznek minősíteni a korszakot, illetve az érintett testületeket. A valóság azonban az, hogy rendkívül alaposan szabályozták azokat a rendvédelmi tevékenységeket, amelyeket a különbözö rendvédelmi testületek láttak el. Emellett pedig a testületeket is számos jogszabályban szabályozták. A rendeletek száma 100-as nagyságrendü. ${ }^{77}$

A Magyar Királyi Csendőrség tevékenységét azért nem szabályozták külön, mivel nem volt hatóság. Az észlelt büncselekményekkel szemben természetesen el kellett járnia. Egyébként azonban a magyar kormány által létrehozott olyan szervezet volt, amely a települések nevében, azok felkérésére végezte tevékenységét. A törvényekben, illetve az önkormányzatok határozataiban foglaltakat volt köteles betartatni, az ellenszegülőkkel szemben eljárni. Tudatlanságot tükröznek azok a vélekedések, amelyek a testület számlájára írják a rend védelme során megvalósított fegyverhasználatokat. A Magyar Királyi Csendőrségnek ugyanis nem állt módjában a közigazgatási hatóságok megkereséseinek az elutasítása, illetve mérlegelése, ha azok nem voltak törvényellenesek. Az intézkedő csendőröknek pedig ugyancsak nem volt választási lehetőségük a rend helyreállítása érdekében alkalmazott eljárásokat illetően. A vonatkozó utasítások egyértelmüek voltak, azoktól eltérni nem lehetett. Ezek a szabályzók pedig a csendőr járör számára nem biztosítottak mérlegelési lehetőséget. ${ }^{78}$

A Magyar Királyi Csendőrséget tulajdonképpen azért hozták létre, mert a falvakban az önkormányzati rendőrségi modell megbukott. Rendőrhatósági jogkörrel ugyan a települések rendelkeztek, azonban a falvak önkormányzatainak nem voltak kellő financiális lehetőségeik ezen modell kivitelezésére. A csendőrséggel lényegében az eredménytelennek bizonyuló vidéki rendőrségi szisztémát váltották fel. A magyar kormányzat — a rossz emlékü császári zsandárság miatt — ugyan kezdetben más megoldást keresett. A rendkívüli hatalommal felruházott királyi biztosok — drákói módszereket alkalmazva - egy-egy térség közbiztonságát ugyan helyreállították, a megbízatásuk lejárta után azonban rövid időn belül visszarendeződött az anarchia. ${ }^{79}$ TISZA István ezt a helyzetet úgy oldotta meg, hogy nem vonta el az önkormányzatok rendőrhatósági jogait, hanem — a központi államhatalom által finanszírozott - olyan országos hatáskörü testületet hozott létre, amelyet a falvak önkormányzatai alkalmazhattak a helyi közbiztonság érdekében. Az önkormányzatok azonban abba már nem szólhattak bele, hogy a csendőrség a rendet milyen módon tartja fenn. ${ }^{\mathbf{8 0}}$

Mivel kezdetben nem állt rendelkezésre kellő számú és a követelményeknek megfelelő jelentkező, ezért a Magyar Királyi Csendőrség személyi állományában jelentkező hiányt a Magyar Királyi Honvédségnél sorkatonai szolgálati kötelezettségüket teljesítők köréből önként jelentkezések alapján kiválasztott honvédekkel pótolták. ${ }^{81} \mathrm{Ez}$ a megoldás azonban nem vált be. Néhány átmeneti év nyomán sikerült a Magyar Királyi Csendőrség legénységi állományát — amely a Magyar Királyi Honvédség altiszti karának a jellegével bírt — hivatásos állományú csendörökkel feltölteni. ${ }^{82}$

A Magyar Királyi Csendőrségnek nem csupán a személyi állománya, hanem a szervezete is fokozatosan alakult ki.

Az 1900-as évek elejére már kiforrott struktúrával rendelkezett. A csendőrség vezető szervezeti egysége a csendőr-felügyelöség volt országos irányítási hatáskörrel. Élén — tábornoki ranggal — a csendőrség felügyelője állt. Alárendeltségébe tartoztak a csendőr kerület-parancsnokságok. A kerületparancsnoki beosztások ezredesi helyek voltak. A csendőr-felügyelöség és a kerület-parancsnokságok 
is szük körü törzzsel - mintegy 15-20 fővel — végezték feladataikat. A kerületek szárnyakból álltak, a szárny-parancsnokságok pedig a szakasz-parancsnokságokat irányították. A szakaszparancsnokságok végezték a csendőrség legkisebb szervezeti egységének, az őrsöknek az irányítását. A csendőrségi diszlokáció eltért a közigazgatási beosztástól. A szakaszok alárendeltségébe különítményeket is lehetett szervezni ideiglenes vagy végleges jelleggel. Állandó különítmény müködött például Gödöllőn a királyi kastély és közvetlen környezete örzése céljából. Ideiglenes különítményeket általában a nyaralóhelyeken állítottak fel. A századelőn állították fel a járásőrmesterségeket - a testületileg illetékes szakasz-parancsnokságok alárendeltségében — amelyek feladatát a bünügyek felderítése képezte. Minden parancsnokság felügyeleti körlete és létszáma akkora volt, hogy azt a parancsnokok felügyelni és irányítani képesek legyenek. Eszerint egy kerület 6-8 szárnyból, egy szárny 2-3 szakaszból, egy szakasz 3-6 - lehetőleg egy közigazgatási járás területén fekvő - örsből állt. ${ }^{83}$

A Magyar Királyi Csendőrség a közbiztonsági szolgálat teljesítésére és gazdászati ügyekre nézve a belügyminiszternek volt alárendelve. Ő állapította meg a csendőrség szárny-, szakasz-, örs- és különítmény parancsnokságok állomáshelyeit, valamint a csendőr kerület-parancsnokságok javaslata alapján az egyes őrsök létszámát. A csendőrségnek ezen kettős alárendeltsége nem jelentett gondot a szervezet irányítását illetően, mert míg a honvédelmi miniszter fennhatósága a testület humán viszonyaival kapcsolatos ügyeire vonatkozott, addig a belügyminiszter fennhatósága kizárólag a közbiztonsági szolgálat teljesítésére és gazdászati ügyekre terjedt ki. Ez a hatásköri megosztás híven tükrözte azt az állapotot, mely szerint a csendőrség rendvédelmi testület volt, a csendőrök azonban személyükben katonának minősültek. A csendőrség rendfokozati rendszere is katonai volt. A Magyar Királyi Honvédelmi Minisztériumban és a Magyar Királyi Belügyminisztériumban a csendőrségi ügyek intézésére külön osztályokat hoztak létre. Ezen osztályok vezetője egy-egy csendőr ezredes volt. Szolgálattételre törzs- és fötiszteket rendeltek be az osztályok.

A Magyar Királyi Honvédelmi Minisztérium 16. (csendőrségi) ügyosztályának ügyköre a csendőr törzs- és fötisztek és legénység mindennemü személyi ügyeit, úgymint:

- a tiszti kinevezésekre, a címbeli rendfokozatok adományozására vonatkozó felelős előterjesztések;

- tervezetének szerkesztését;

- felülvizsgálati, nyugdíjazásbeli és kegydíj ügyeket;

- tiszti és legénységi egyének kitüntetése és jutalmazása iránti előterjesztéseket;

- tisztek, tisztjelöltek minősítményi táblázatainak megőrzését;

- tisztjelöltek (hadapródok) és számvivő-tiszthelyettesek kinevezését és tiszti kinevezésük iránti elöterjesztéseket;

- csendőrtisztek és tisztjelöltek beosztását, áthelyezését és vezénylését;

- szabadságolásokat;

- tiszti rendfokozatról való lemondásokat;

- szolgálaton kívüli viszonyba való helyezéseket;

- csendőrség kötelékéből való elbocsátásokat;

- rangmeghatározásokat;

- tisztek és legénység szolgálati idejének megállapításaira vonatkozó tárgyalásokat;

- polgári államhivatalba való átlépéseket foglalta magába. ${ }^{84}$

Az osztály hatáskörébe tartozott még a csendőrtisztek és tisztjelöltek rangsorozati és beosztási lajstromának nyilvántartása, állománykiegészítési ügyei. Nemességek és előnevek. Személyi és sebesülési pótdíjak. A csendőrség legénységi és lóállományának rendszeresítése, kiegészítése és nyilvántartása. A csendőrlegénység szabadságolási, felülvizsgálati és nyugdíjazási ügyei. A csendőrlegénység közigazgatási úton való eltávolítása. Csendőregyéneket illető alapítványok felügyelete. Elmebeteg csendőri egyének elhelyezése. Névváltozásra vonatkozó ügyek. A csendőrség szolgálata és szakszerü kiképzése iránti intézkedések, valamint a csendőrség szolgálati könyveinek és utasításainak kidolgozása. Öltözeti és felszerelési ügyek. Mozgósítási ügyek. Csendörtisztek és legénység ellen irányuló panaszok kivizsgálása és csendőri szempontból való elbírálása.

A Magyar Királyi Honvédelmi Minisztériumban a csendőrségi ügyosztályt a csendőrségnek az egész országra történő kiterjesztése során már létrehozták. A Magyar Királyi Belügyminisztériumban 1904-ben szerveztek külön csendőri osztályt. Mindkét minisztériumban a csendőrségi osztályok a az Osztrák-Magyar Monarchia összeomlásáig müködtek. 1897-ben hozták létre a csendőrségi felügyelöséget. Korábban a Magyar Királyi Csendőrség a Magyar Királyi Honvéd főparancsnokságnak úgynevezett bírói hatalma alatt állt. A csendör-kerületeket a honvéd kerületi és dandár-parancsnokok is szemlézték. A dualizmus időszakában az alapvető szervezeti struktúra - mely szerint az ország terü- 
lete csendőr kerületekre, a kerületek szárnyakra, a szárnyak szakaszokra, a szakaszok pedig őrsökre oszlottak - nem változott. ${ }^{85}$

Némileg módosította a szervezeti felépítést az 1899. I. 1-jén hatályba lépő új polgári bünvádi perrendtartás, mely a Magyar Királyi Csendőrség nyomozási eljárását módosította. Ennek alapján a csendőr tisztek nem minősültek rendőri közegnek. Korábban olyan gyakorlat alakult ki, hogy a csendőr tisztek fontosabb esetekben személyesen vezették a nyomozásokat. A törvény alapján a nyomozati munkából kieső csendőr tisztek pótlására hozták létre a járás-parancsnokságokat 1903-tőlo. ${ }^{\mathbf{8 6}}$

Ugyancsak 1904-ben alapították a Magyar Királyi Csendőrség Felszerelési és Anyagraktárát. A csendőrségi központi anyagraktár létrehozásának alapvetően két oka volt. Egyrészt a Magyar Királyi Csendőr-felügyelőség létrehozásával szervezetileg távolodott a honvédségtől — bár teljesen nem szakadt el - másrészt pedig a szervezet fejlődése folytán, a korabeli honvéd alakulatokétól fegyverzete és felszerelése némileg eltérővé vált. Az anyagraktár két tiszt vezetése alatt állt, a parancsnoki beosztás fötanácsosi ranggal, az úgynevezett átvevőtiszti munkakör pedig századosi számvevő ranggal járt. Rajtuk kívül hat törzsőrmester és a szolgaszemélyzet dolgozott az anyagraktárban.

1907-ben szervezték meg a csendőrség lovakkal történő ellátásának biztosítása érdekében a Magyar Királyi Csendőrség Pótlóidomító Osztályát, mely elöször Cegléden, majd Zomboron müködött, később pedig átköltöztették Kiskunhalasra. A pótlóidomító osztályon parancsnoki beosztásban egy tiszt — általában főhadnagy — alárendeltségében pedig hat-tíz altiszt dolgozott. Rajtuk kívül még állatorvost és úgynevezett szolgaszemélyzetet is alkalmaztak.

Az Országos Csendőriskola 1909-ben nyílt meg Nagyváradon, korszerü iskolaépületet és felszerelést pedig 1913-ban kapott. Ekkor; keresztelték át Magyar Királyi Csendőr Továbbképző és Altiszti Iskolára. Itt hét tiszt tanított tanári beosztásban századosi és főhadnagyi rendfokozatban. Az iskolaparancsnoki beosztás alezredes hely volt. A tanári karon kívül segédoktatóként 10 altisztet is alkalmaztak.

1907-re valamennyi csendőr kerületnél létrehozták a pótszárnyat. A pótszárny nem látott el közvetlen szolgálati feladatokat hatósági területtel sem rendelkezett. Feladatát elsősorban a gazdasági ügyek intézése, a csendőrök alapkiképzése és egyéb nem kifejezetten szolgálati teendők ellátása jelentette. A szervezeti egységek száma jelentősen nőtt a megalakulástól az I. világháborúig. Természetesen a szervezeti egységek növekedésével a létszám is emelkedett. A Magyar Királyi Csendőrség a század végére felzárkózott az osztrák örökös tartományokban 1850 óta megszakítás nélkül müködö csendőrséghez. ${ }^{87}$

Az erőteljesebb szervezeti és létszámfejlődés szorosan összefüggött az országban kialakult közbiztonsági helyzettel. 1885-ben még - amikor az eredetileg tervezett hat csendőrkerület felállítása már megtörtént - 1200 honvéddel pótolták ideiglenesen a hiányzó csendőr legénységet. A kerületek kiépítése folyamatosan történt. A kerületek szolgálatukat szilveszter éjszakáján kezdték meg. Már előzőleg tájékozódtak azok felöl, akik; közismerten bünöző életmódot folytattak. Az ö lefogásukkal kezdték a csendőrök szolgálatukat.

Az 1890-es évek nagy agrársztrájkjai hatására több ízben növelték a Magyar Királyi Csendőrség létszámát. Új szárnyakat, szakaszokat, őrsöket hoztak létre. Hasonló módon hatottak a csendőrség szervezetére a századfordulóra felerősödő azon nemzetiségi mozgalmak is, amelyek szembekerültek az Osztrák-Magyar Monarchia területi egységével. Amikor a történelmi Magyarországnak a Királyhágón túli vármegyéiben aktivizálódott a román soviniszta mozgalom, a kolozsvári csendőr-kerületet megerösítették. $^{\mathbf{8}}$

1894-ben egyes szakaszok területét ideiglenes jelleggel kisebb szakaszokra osztották fel. Ebben az évben végleges jelleggel új szárnyparancsnokságokat, valamint 33 örsöt is hoztak létre. A személyi állományt három tiszttel, 33 altiszttel és 149 csendörrel növelték. A századfordulón Erdélyben 37 szakaszparancsnokságot, 7 szárnyparancsnokságot, 127 örsöt állítottak fel, ezzel egyidőben 57 tiszttel, 127 altiszttel és 586 csendőrrel növelték a szervezet létszámát. E mellett a már müködő őrsök létszámát 255 fövel emelték. ${ }^{89}$

A Magyar Királyi Csendőrség eredményesnek mondható bűnüldöző tevékenységéhez — az egész országra kiterjedő egységes szervezeten és szolgálati elveken kívül — valószínúleg az is hozzájárult, hogy a Magyar Királyi Csendőrség személyi állománya a társ fegyveres erők és testületek, valamint a polgári államapparátus beosztottaihoz képest is előnyösebb helyzetben volt. Az előnyösebb helyzetet biztosította többek között az az intézkedés is, hogy a határszéli csendörség személyi állományából a magyar-szerb és a magyar-román határon szolgálatot teljesítő tagok szolgálati idejét duplán számították 1908-tól. Különböző alapítványok is segítették a személyi állomány élet- és szolgálati körülményeit. Az „I. Ferenc József Alapítvány” például 21000 korona értékben járult hozzá a Magyar Királyi 
Csendőrség tagjainak üdültetéséhez, vagy a „Bernfeld Mór Alapítvány”, mely 41000 korona értékben az elhunyt csendörök hozzátartozóit segélyezte. ${ }^{90}$

Az államhatalmon belüli intézkedések is számos előnyt nyújtottak a Magyar Királyi Csendôrség tagjainak, pld. a három gyerekes apák gyerekenként 100 korona családi pótlékot kaptak. A tiszti állomány nyugdíjába beszámították a csendőrségi pótlékot is. Aki a hatvanadik életévében a harmincöt éves szolgálati időt még nem töltötte be, azokat a harmincötödik szolgálati évük leteltéig csak ideiglenesen nyugdíjazták. Ezáltal jóval magasabb nyugdíjhoz juthattak. Rendkívül tágan értelmezték a szolgálat ellátásából adódó munkaképesség csökkenést is. Így lehetővé vált, hogy a tartósan megbetegedett, részlegesen vagy teljesen szolgálatképtelenné vált csendőrök a fizetésükkel megegyező nyugdíjat kaphassanak. Figyelemre méltó a hatalmon lévők gesztusa a csendőrség irányába abban az időszakban, amikor az államapparátust megpróbálták csökkenteni, a bürokráciát visszaszorítani, a kiadásokat mérsékelni. ${ }^{91}$

A csendörség személyi állományát gondosan válogatták. Az új csendőröket elméleti és gyakorlati oktatás után vezényelték végrehajtó szolgálatba.

Az altisztek előléptetését huzamosabb ideig végzett kiváló szolgálatellátáshoz és elméleti vizsgához kötötték.

Az őrsvezetővé való előléptetés az altiszti vizsga jó eredményétől függött, melyet a törzsnél teljesítendő elméleti oktatás előzött meg.

1909-től Nagyváradon, az új központi csendőr iskolán folyt az altisztek képzése. A csendőrtiszti állomány kiegészítése alapvetően két úton történt. Az egyik lehetőség az altisztek előléptetése volt megfelelő képzés után. A Magyar Királyi Honvéd Ludovika Akadémia szabadságolt állományú honvéd-tiszti tanfolyamába minden évben a tiszti állomány kiegészítésére előreláthatólag szükséges számú csendőr altisztet vezényeltek.

A csendőrtisztek pótlására még egy lehetőséget jelentett a közös hadseregben és a Magyar Királyi Honvédségnél szolgálatot teljesítő tisztek átvétele. Csendőr tisztté történő kinevezésükhöz különbözeti vizsgát kellett letenniük, az úgynevezett csendőrségi szakvizsgát. ${ }^{92}$

1868-ban, amikor az Osztrák-Magyar Monarchiában a csendőrség egyenruháját módosították az erdélyi X. és a horvátországi VIII. számú csendőr parancsnokság egyenruhája is módosult. Ekkor rendszeresítették részükre a vadászkalapot, a korábban kétsoros kabát helyett az egysoros gombbal ellátott kabátot. Ez volt az öltözéke a magyarországi csendőrségnek 1876-ig. Ekkor csupán annyiban módosították, hogy a császári címerü gombokat a Magyar Királyi Honvédség gombjaival váltották fel és a vadászkalap sapkarózsáját - mely lángoló gránátot ábrázolt - a magyar címerrel cserélték fel, valamint a zubbonyra a Magyar Királyi Honvédségnél használt zsinórzatot rendszeresítették. 1881-ben ezt az ékítményt vette át a Magyar Királyi Csendőrség, amelyet azonban már a honvédségnél használatos egyenruhára helyeztek, bár az úgynevezett vadászkalap és a kétsoros zubbony továbbra is rendszeresített ruhadarab maradt. Így tehát a Magyar Királyi Csendőrség ruházata — a gombok és a zsinórzat, valamint a sapkarózsa kivételével — azonos volt ugyan a császári csendőrségével, az ékítmények tekintetében azonban a Magyar Királyi Honvédségével egyezett meg. Kisebb módosítást jelentett, hogy 1910-ben rendszeresítették az ujjas vállgallért, valamint, hogy a szürke bőrkesztyü színét barnára változtatták és megengedték a nyaksál viseletét, külön a tisztek számára barna lábszárvédőt, a legénység részére pedig - a tisztekéhez hasonló, a korábbinál díszesebb kivitelü — sapkát rendszeresítettek. 1912-ben vezették be a rejtett gombolású zubbonyt. A háború alatt a Magyar Királyi Csendőrség egyenruházatának pótlását nem tudták megoldani, így először a tábori csendőrség, majd a teljes csendőrség személyi állománya a hadsereg csukaszürke egyenruháját viselte. ${ }^{93}$

A Magyar Királyi Csendőrség fegyverzete és felszerelése is mérsékelten fejlődött az I. világháborúig. A Magyar Királyi Csendőrség nem tért át a lovak használatáról a kerékpárra, mint a Magyar Királyi Pénzügyőrség, ahol a századfordulón már sokan szolgálati kerékpárral teljesítették feladatukat. Szíjazatként 1868-tól fekete lakk szíj volt rendszeresítve, ezt 1904-től barna színüvel cserélték fel. A Magyar Királyi Csendőrség szolgálati felszerelése tulajdonképpen rendkívül egyszerü volt. Gyalogosoknál karabélyból, kardból, járőrtáskából, kézibilincsből és jegyzetfüzetből állt, mely lovasoknál a nyereggel és a lószerszámmal egészült ki. ${ }^{94}$

A haditechnika fejlődésével természetesen a Magyar Királyi Csendőrség fegyverzetét is többször módosították. 1868-ban új hátul töltő puskát kapott a csendőr legénység, melyet azonban már 1876ban Fruhwirth-típusú ismétlő karabélyokkal cserélték fel. 1887-re a modernebb Kropatschek-féle karabélyt rendszeresítették, melyet 1906-ban a Mannlicher karabéllyal váltottak fel. Ehhez 1913-ig úgynevezett béketöltényeket használtak. A béketöltényeket még füstös lőporral töltötték, míg a haditöltényeket már — a maihoz hasonlóan — füst nélkülivel. A Mannlicher karabélyokhoz külön csendörségi 
szuronyokat készítettek. 1912-ig a kard mellett oldalfegyverként forgópisztollyal látták el a csendőrség személyi állományát. 1912-től a forgópisztolyt a Frommer-féle önmüködő pisztollyal váltották fel. ${ }^{95}$

A csendőr tisztek rendfokozata megegyezett a honvéd tisztekével. A Magyar Királyi Csendőrség felügyelője tábornoki rangot viselt. A kerületi parancsnokok ezredesei, a kerület törzsben dolgozók, valamint a kikülönített törzstisztek alezredesi és örnagyi, a szárny- és szakasz-parancsnokok pedig századosi, illetve főhadnagyi rendfokozatot kaptak. ${ }^{96}$

A legénység rendfokozata több ízben változott. Kezdetben a közcsendör tizedesi rendfokozatot viselt. Az örsparancsnokok — akiket örsvezetőnek hívtak — örmesteri rendfokozatot kaptak. 1900-tól rendszeresítették elsősorban az alacsonyabb gazdászati beosztásokhoz a törzsőrmesteri rangot. 1901től a közös hadseregtől, valamint a Magyar Királyi Honvédségtől a Magyar Királyi Csendőrséghez került őrmesterek és szakaszvezetők címzetes őrsvezetői rangot kaptak, melyet 1904-től az öt évet szolgált csendőrök is megkaptak. 1904-től a járás-parancsnokok részére rendszeresítették a járásőrmesteri rendfokozatot. A nagyváradi központi csendőriskola felállítása után az ott kimagasló eredménnyel végzök címzetes örmesteri rangot kaptak. Az Osztrák-Magyar Monarchia magyarországi csendőrségének rendfokozatait véglegesen 1916-ban rendezték. ${ }^{97}$

Összességében a Magyar Királyságban a rendvédelmi rendszer egyedi volt, mivel a dualista államalakulat két társországa a rend védelmét önállóan szervezte. Természetesen akadtak hasonlóságok is a közös történelmi múltból a korabeli rendvédelem fejlődési tendenciáiból és a hasonló gazdasági, illetve társadalmi körülményekből, továbbá a közös, illetve hasonló közigazgatási és jogrendszerből fakadóan. Mégis a magyarországi csendőrség, rendőrségek és határőrizeti szervezetek idegen érdekektől függetlenül jöttek létre és müködtek. Létrehozásuk és tevékenységük a magyar rendvédelem fejlödéstörténetének következményei voltak. Ez természetesen nem jelentette azt, hogy a magyar rendvédelem fejlesztése terén az ország vezetése elzárkózott volna a külföldi tapasztalatok adaptálása elöl. ${ }^{\mathbf{9 8}}$

Ennek a helyzetnek talán a legjellemzőbb megnyilvánulási formája a kivételes hatalom időszakában a rendvédelem múködésének szabályozása volt. A kivételes hatalom időszaka alatt a fegyveres konfliktus idejét értették, amikor a demokratikus jogok korlátozás alá kerültek. A XIX-XX. század fordulóján Európa-szerte szabályozták a kivételes hatalom időszakát. Ennek során kétféle koncepció jött létre. A brit elképzelés szerint a kivételes hatalom gyakorlását a polgári közigazgatás valósítja meg. Ezzel szemben a német felfogás szerint a kivételes hatalmat a haderőnek kell gyakorolnia. Az Osztrák-Magyar Monarchia két társországában nem azonos koncepciót követtek. Az Osztrák Császárságban a német minta szerint törvényben szabályozták a kivételes hatalom időszakát. A Magyar Királyságban pedig — ahol az osztrák szabályozást követően foglalkoztak a témakörrel — a brit mintát követték. ${ }^{99}$

A magyar országgyülés 1912-ben foglalta törvénybe a kivételes hatalom gyakorlását. 1912-től vált intenzívvé a valószínüsíthető hadműveleti irányok határmenti rendvédelmi testületeivel — elsősorban a határörizeti feladatokat ellátó rendvédelmi szervezetekkel - a területileg illetékes hadtestparancsnokságok vezérkari osztályainak kapcsolata. A hadmüveleti tervek számára felmérték a határmenti rendvédelmi szervezetek képességeit és e képességeknek megfelelő feladatokat terveztek a számukra, illetve ha szükséges volt e képességeket felerősítették. ${ }^{\mathbf{1 0 0}}$

A magyar határörizeti szervezetek közül elsősorban a határszéli csendőrséget és a határszéli pénzügyőrséget érintették a hadmüveleti tervek. Ezen alakulatok személyi és tárgyi feltételrendszerén jelentős módosításokat eszközöltek annak érdekében, hogy a képességeiket összhangba hozzák a rájuk váró feladatokkal. ${ }^{101}$

A polgári magyar állam rendvédelme a magyar hagyományok és a nyugat-európai tapasztalatok alapján fokozatosan alakult ki. A magyar rendvédelem-történet ezen időszakát a központi államhatalom rendvédelemben betöltött szerepének a gyarapodása jellemezte ugyan, azonban a feladatkörök koránt sem tekinthetők monopóliumnak, sőt - miután a falvak esetében látványosan megbukott az önkormányzati rendőrség modellje — a községek rendőrhatósági jogkörét az országgyülés nem vonta el. Ehelyett létrehozott egy olyan - a törvényhatósági jogú városok hatósági területének kivételével, az egész ország területére kiterjedő - rendvédelmi testületet a Magyar Királyi Csendőrséget, amelyet a kis települések önkormányzatai használhattak a rend fenntartása érdekében. A dualizmuskori Magyar Királyság rendvédelmének kétség kívül a Magyar Királyi Csendörség létrehozása és müködtetése volt a legfontosabb eleme, mivel ezen szervezet alkalmazásával hozták létre az ország területének túlnyomó többségén és a lakosság döntő többségének a körében a közbiztonságot. ${ }^{102} \mathrm{~A}$ magyar rendvédelem testületei voltak: a Magyar Királyi Csendőrség (1881), magyarországi rendőségek — városonként önálló rendörségek müködtek, az állam pedig csupán a legexponáltabb területeken hozott létre a kormánynak közvetlenül alárendelet rendőrségeket, ilyen volt a fővárosi rendőrség (1872), a Magyar Királyi Határrendőrség (1906) és a Fiumei Magyar Királyi Állami Rendőrség (1916) - a Magyar Kirá- 
lyi Pénzügyőrség (1867), a Magyar Királyi Nemesi Testőrség (reorganizálva 1867), a Magyar Királyi Darabont Testőrség (1904), a Magyar Királyi Képviselőházi őrség (1912), a Magyar Királyi Koronaőrség (reorganizálva 1867), és a büntetés-végrehajtás fokozatosan fejlődő intézménye. ${ }^{103}$

A dualizmuskori magyar rendvédelem legerösebb pillérei kétség kívül a Magyar Királyi Csendörség, a rendőrségek és a határőrizeti szervezetek voltak. A rendvédelemben foglalkoztatottak több mint $70 \%$-a a csendőrség és a rendőrségek körében teljesített szolgálatot. ${ }^{104}$

Ezen belül foglalt el tekintélyes helyet a határörizet. A határörizeti struktúra fokozatosan alakult ki. Annak ellenére, hogy a határőrizet tekintetében a Magyar Királyság az Osztrák-Magyar Monarchiában az Európai Unió béli Magyarországhoz hasonló helyzetben volt, a korabeli vezetők az ezredforduló utáni magyar megoldástól eltérő utat választottak. A dualizmuskori Magyarországon ugyanis nem hoztak létre önálló határörséget, hanem a részhatárőrizeti feladatokat a már müködő azon rendvédelmi testületekre bízták, amelyek alapfeladata harmonizált az adott részhatárórizeti teendővel. Végül pedig a határőrizeti teendők koordinálására és egyes részhatárőrizeti feladatok ellátására egy önálló — bár nem nagy létszámú - szervezetet hoztak létre a Magyar Királyi Határrendőrséget. A Magyar Királyság határörizetében foglalkoztatottak száma (mintegy 3000 fö), a magyar fegyveres rendvédelmi testületek személyi állományának (csaknem 33000 fö) közel $10 \%$-át alkotta. ${ }^{105}$

A dualizmuskori magyar rendvédelem még háború időszakában sem került — a hadmüveleti területek kivételével — a haderő alárendeltségébe. A magyarországi rendszerváltás után a magukat liberálisnak nevező köröknél elterjedt a militarizmus téves értelmezése. Nevezetesen azért is neveznek militarizmusnak mindent, ahol rendfokozat és egyenruha és a katonai függelmi viszonyok felbukkannak. Egyben pedig úgy foglaltak állást, mintha a militarizmus eleve káros jelenség volna minden időben és minden területen. E téveszmét cáfolja, hogy a dualizmus időszakában a katonai függelmi viszonyok szerint müködő Magyar Királyi Csendőrség volt Magyarország legeredményesebb rendvédelmi szervezete, mivel - a létrehozás éveit és a háború időszakát leszámítva - $90 \%$ körüli bünfelderítési eredményt ért el. Természetesen nem lehet egy szervezetet csupán a belső függelmi viszonyai alapján militánsnak nevezni, különösen akkor nem ha a testület — mint például a Magyar Királyi Csendőrség — szinte valamennyi testületi paramétere alapján alkalmatlan lett volna katonai műveletek megvalósítására. Ez alól talán csupán a békefenntartás volt kivétel, bár akkor még nem ezt a terminológiát használták. ${ }^{106}$

A dualizmuskori magyar rendvédelem megítélése, a keletkezett tapasztalatok értelmezése tekintetében azért elfogadhatatlan a liberális álláspont, mivel a katonai függelmi viszonyok szerint működő szervezet teremtett végül is rendet az országban. A liberális nézeteket vallók éppen azt tartják helytelennek, ami által a csendőrség alkalmassá vált a hivatása betöltésére. A militarizmus gyülöletén nyugvó szemléletmód olyan prekoncepciót képvisel, amely akadályozza a téma objektív történelemszemléletén nyugvó értelmezését. Ez a jelenség figyelemre méltó, hiszen néhány évtizeddel korábban egy másik prekoncepció az osztály alapon nyugvó elöítéletek miatt tekintették helytelennek azt a rendvédelmet, amelynél hatékonyabbat a későbbi korok sem tudtak még létrehozni. ${ }^{107}$

A polgári magyar állam rendvédelmének dualizmuskori időszaka az i. világháború és azt követő forradalmak időszakával zárult. A vesztes háború és következményei olyan helyzet elé állították a magyar állam rendvédelmi rendszerét, amelynek az eredményes kezelésére nem rendelkezett kellö képességekkel, illetve ha ilyen képességei lettek volna, valószínúleg akkor sem lett volna képes a folyamatokat megakadályozni. Az önkormányzatok és a jelentősebb földbirtokosok miliciákat szerveztek a helyi rend fenntartása érdekében mivel a frontokról hazaözönlö fegyveres tömegek kezelésére a magyar rendvédelmi rendszer alkalmatlannak bizonyult. 


\section{Jegyzetek:}

${ }^{1}$ DEÁK: Egy régi politikai rendszerváltás és az államrendőrség.

${ }^{2}$ CsIZMADIA : 192-194.p.

${ }^{3}$ GALÁNTAI : 20-64.p.

${ }^{4}$ ZACHAR

${ }^{5}$ CSAPÓ: A Magyar Királyi Csendörség története 1881-1914. 13-19.p.

${ }^{6} 1881 /$ II.tc. ; 1881/III.tc.

${ }^{7}$ TISZA

${ }^{8}$ CSIZMADIA : op.cit. 132.p.

${ }^{9}$ 1886/XXI.tc. $80 . \S$

${ }^{10} 1872 / X X X V I . t c . ; 1881 / X X I . t c$.

11 1903VIII.tc. ; 1916/XXXVII.tc.

12 O'SVÁth

${ }^{13}$ TISZA : op.cit.

${ }^{14}$ Loc.cit.

${ }^{15}$ VÉCSEY

${ }^{16}$ DORNING

${ }^{17}$ BORBÉLY - KAPY

${ }^{18}$ CZAGA - HORVÁTH - JANCSÓ

${ }^{19}$ BORBÉLY - KAPY : op.cit.

${ }^{20} 1897 / X X X I V . t c . \quad ; \quad 24$ 300/1908.IM.r.

${ }^{21} \mathrm{NAGY}$

${ }^{22}$ PARÁDI : A magyar rendvédelem története. 320-322.p.

${ }^{23}$ DEÁK: Államrendőrségi információs hálózat Magyarországon 1849-1867.

${ }^{24}$ ERNYES

25 1870/XLII.tc. ; 1871/XVIII.tc. ; $\quad$ 1872/XXXVI.tc. op.cit. ; 1881/XXI.tc.op.cit. 1903/VIII.tc.op.cit. ; 1916/XXXVII.tc. op.cit.

${ }^{26}$ PONGRÁCZ - LUKÁCS

${ }^{27}$ PARÁDI : Pénzügyörség és vámhivatalok a határörizetben. 31-33.p.

${ }^{28}$ WitTINGHeit

${ }^{29}$ HuSZÁR - VILSINSZKY

${ }^{30}$ Loc.cit.

${ }^{31}$ Loc.cit.

${ }^{32}$ EXNER

${ }^{33}$ Loc.cit.

${ }^{34}$ PARÁDI: A Magyar Királyi pénzügyminisztérium határőrizeti feladatai az Osztrák-Magyar Monarchia magyarországi vámhatárain 1867-1914.

${ }^{35}$ Loc.cit.

${ }^{36}$ PARÁDI: A dualizmuskori magyar pénzügyőrség és vámhivatalok.

${ }^{37}$ Loc.cit.

${ }^{38}$ PARÁDI: Pénzügyőrség és vámhivatalok a dualizmus korában. I.rész.

${ }^{39}$ PARÁDI: Pénzügyőrség és vámhivatalok a dualizmus korában. II.rész.

40 THÚRÓCZY

${ }^{41}$ Loc.cit.

${ }^{42}$ MÁRfFY

${ }^{43}$ Magyarország tiszti czím- és névtára 1870-1814. Vámhivatali fejezetek.

${ }^{44} 1888$ /XIV.tc.

45 50 431/1891.BM.r. : $1 . \S$

${ }^{46}$ Loc.cit.

${ }^{47}$ PARÁDI: A határszéli csendörség 1891-1914.

${ }^{48}$ OLÁH

${ }^{49}$ PARÁDI: A Magyar Királyi Csendőrség határőrizeti feladatai 1891-1914.

${ }^{50}$ PARÁDI: A magyar határőrizet tere a kiegyezéstől a második világháborúig.

51 5692/1905.ME.r.

5291 000/1905.BM.kr.

${ }^{53}$ PARÁDI: A polgári magyar állam első határőrizeti szakszerve a Magyar Királyi Határrendőrség 1906-1914.

${ }^{54}$ PARÁDI: A Magyar Királyi Határrendőrség a magyar határőrizet szakmai vezető testülete.

${ }^{55}$ PARÁDI: Rendörség a határörizetben.

${ }^{56}$ PARÁDI: A Magyar Királyi Határrendőrség.

${ }^{57}$ PARÁDI: A polgári magyar állam rendvédelmi testületeinek humán viszonyai 1867-1945.

${ }^{58}$ PARÁDI: Rendőrség a magyar határörizetben. 
${ }^{59}$ PARÁDI: A dualista Magyarország határőrizete 1867-1914. 40-45.p. ; 153 358/1913.BM.r. kolerával fertőzött vidékekröl érkező utasok ellenörzése.

${ }^{60}$ PARÁDI: A Magyar Királyság határrendőrsége.

${ }^{61} 1881 /$ III.tc. : op.cit.

$621882 /$ X.tc.

${ }^{63}$ ÖRY

${ }^{64}$ PRESZLY

${ }^{65}$ ZACHAR : op.cit.

${ }^{66}$ REKTOR : 44-67.p.

${ }^{67}$ CSAPÓ : A Magyar Királyi Csendőrség története 1881-1914. op.cit. 14-18.p.

${ }^{68}$ Loc.cit. 19.p.

${ }^{69}$ PARÁDI: A Magyar Királyi Csendőrség megalakulása és működése 1881-1918.

${ }^{70}$ Loc.cit.

${ }^{71}$ PARÁDI: A polgári magyar állam első központosított közbiztonsági szerve a Magyar Királyi Csendőrség.

${ }^{72}$ Loc.cit.

${ }^{73}$ A csendőrségröl szóló törvény uralkodói szentesítésének napját tekintették a testület napjának, melyet 1933-tól minden évben minden csendőr megünnepelt még az emigrációban és a fogságban is, természetesen a körülményei függvényében.

PARÁDI: Elpusztított emlékhelyek. Rendvédelem-történeti Hirlevél (Nuntiotones Historiae Preasidii Ordinis), XVII.évf. (2008) 29-30.sz. 96-109.p. HU-ISSN 1785-3257.

${ }^{74}$ PARÁDI: A magyar rendvédelem története. : 68-100.p.

${ }^{75}$ SZAKÁLY: A magyar királyi csendőrség, az első központosított magyar közbiztonsági őrtestület.

${ }^{76}$ PARÁDI: A csendőr tisztképzés és a fizetési osztályokba sorolt állam alkalmazottak szakvizsgarendszere.

${ }^{77}$ A testületre vonatkozó jogszabályok a „Csendőrségi Közlöny”-ben I-XIII.évf. (1907-1919) és XIV.-XXXIV.évf. (19241944), a „Csendőrségi és Rendőrségi Közlöny”-ben I-VIII.évf. (1916-1923), a „Rendeleti közlöny a Magyar Királyi Honvédség számára” I-LXXI.évf. (1874-1944), a „Belügyi Közlöny”-ben I-XLVIII.évf. (1896-1944) jelentek meg. A „Rendeleti Közlöny a Magyar Királyi Honvédség számára” 1918. és 1919. évben „Rendeleti Közlöny a Magyar Honvédség számára”, az 1920. és 1921. években pedig „Rendeleti Közlöny a Magyar Királyi Nemzeti Hadsereg számára” címmel jelent meg.

${ }^{78}$ PARÁDI: A Magyar Királyi Csendőrség szolgálati tevékenységei.

${ }^{79}$ CsAPÓ: Ráday Gedeon és a szegedi királyi biztosság. A betyárvilág felszámolása.

${ }^{80}$ PARÁDI: A Magyar Királyi Csendőrség szolgálati tevékenységei. : op.cit.

81 1883/XXVII.tc.

${ }^{82}$ CSAPÓ: A Magyar Királyi Csendőrség története 1881-1914. :op.cit.

${ }^{83}$ PARÁDI: A Magyar Királyi Csendőrség szervezete.

${ }^{84}$ SZAKÁLY: A Magyar Királyi Csendőrség 1919-1941.

${ }^{85}$ Loc.cit.

${ }^{86}$ PARÁDI: A Magyar Királyi Csendőrség szolgálati tevékenységei. : op.cit.

${ }^{87}$ Idem: A Magyar Királyi Csendőrség szervezete. : op.cit.

${ }^{88}$ PARÁDI: Tények és érzelmek egy hajdani magyar rendvédelmi testület története kapcsán.

${ }^{89}$ Ilyen ideiglenes szakaszokat hoztak létre: Balázsfalván, Brádon, Topánfalván, Szászrégenben, Szászvárosban, Szászsebesen, Fogarason, Székelyudvarhelyen, Gyergyószentmiklóson, Dicsőszentmártonban, Kézdivásárhelyen, Désen és Mezőörvényesen, valamint Nagyilodán. Új szárny-parancsnokságot állítottak föl Nagykárolyban, és két új szakasz-parancsnokságot Margittán és Nagybányán.

Csendőrségi Lapok (szerk.): Zsebkönyv a Magyar Királyi Csendörség számára 1894.

${ }^{90}$ PARÁDI: Elpusztított emlékhelyek: op.cit.

${ }^{91}$ PARÁDI: A polgári magyar állam rendvédelmi testületeinek humán viszonyai 1867-1945. : op.cit.

${ }^{92}$ PARÁDI József: Rendvédelmünk képzési és képesítési rendszere 1867-1945.

${ }^{93}$ ZEIDLER: A Magyar Királyi Csendőrség rendfokozati rendszere és jelvényei.

${ }^{94}$ Loc.cit.

${ }^{95}$ LugOSI: A rendvédelmi testületek fegyverei 1867-1918.

${ }^{96}$ OLASZ — PARÁDI — ZEIDLER : A magyar rendvédelmi testületek rendfokozati rendszere a kiegyezéstől az ezredfordulóig.

${ }^{97}$ Loc.cit.

${ }^{98}$ PARÁDI: A dualizmus közrendvédelmi szerveinek jellemzői és tevékenységük tapasztalatai.

${ }^{99}$ MEZEY

${ }^{100}$ PARÁDI Áttérés a háborús határőrizetre az első világháború előtt.

${ }^{101}$ Loc.cit.

${ }^{102}$ PARÁDI: A dualizmus közrendvédelmi szerveinek jellemzői és tevékenységük tapasztalatai. : op.cit.

${ }^{103}$ PARÁDI: A magyar rendvédelem története. : op.cit. 68-100.p.

${ }^{104}$ Loc.cit.

${ }^{105}$ PARÁDI: A történelmi Magyarország határőrizeti tapasztalatai.

${ }^{106}$ PARÁDI: A Magyar Királyság rendvédelme 1867-1919.

${ }^{107}$ PARÁDI: Rendvédelem vagy rendészet.

\section{Jegyzetekben alkalmazott röviditések:}

\section{MONOGRÁFIÁK ÉS KISMONOGRÁFIÁK}

BORBÉLY - KAPY

CZAGA - HoRvÁTH - JANCSÓ
BORBÉLy Zoltán - KAPY Rezső (szerk.): A 60 éves magyar rendörség 1881-1941. Budapest, 1942, Halász Irodalmi és Könyvkiadó Vállalat. 594 p.

CzAga Viktória - HoRvÁth J. András - Jancsó Éva et al.: A fơvárosi rendörség története 1914-ig. Budapest, 1995, Budapesti Rendőrfőkapitányság. 578 p. HU-ISBN 9630339927. 
Csapó: A Magyar Királyi Csendörség története 1881-1914.

CsAPó: Ráday Gedeon és a szegedi királyi biztosság. A betyárvilág felszámolása.

CSIZMADiA

DORNING

ERNYES

EXNER

GALÁNTAI

HUSZÁR - VILSINSZKY

OlÁH

O’SVÁTH

PARÁDI: A határszéli csendörség 18911914.

PARÁDI: A magyar rendvédelem története.

PARÁDI: Pénzügyörség és vámhivatalok a határőrizetben.

PARÁDI: Rendörség a határörizetben.

PONGRÁCZ — LUKÁCS

PRESZLY

REKTOR

TISZA

VÉCSEY

WITTINGHEIT

\section{TANULMÁNYOK}

DEÁK

DEÁK: Államrendőrségi információs hálózat Magyarországon 1849-1867.

Lugosi: A rendvédelmi testületek fegyverei 1867-1918.
Csapó Csaba: A Magyar Királyi Csendörség története 1881-1914. Pécs, 1999, Pro Pannónia Kiadói Alapítvány. 186 p. HU-ISBN 9639079405. /Pannónia Könyvek./ HU-ISSN 0237-4277.

Csapó Csaba: Ráday Gedeon és a szegedi királyi biztosság. A „,betyárvilág” felszámolása. Pécs, Pro Pannónia Kiadó. 204 p. HU-ISBN 97896394 9887 7. /Pannónia könyvek./ HU-ISSN 0237-4277.

- Csizmadia Andor: A magyar közigazgatás fejlödése a XVIII. századtól a tanácsrendszer létrejöttéig. Budapest, 1976, Akadémia Kiadó. 560 p. HUISBN 9630507137.

- DoRning Henrik: A rendörség intézményének fejlödése. Budapest, 1922, Atheneum.

- ERnyes Mihály: A magyar rendörség története. Budapest, 2002, Belügyminisztérium. 342 p. HU-ISBN 9639208140.

- EXner Kornél: Pénzügyigazgatás 1901-1910. Budapest, 1911, Országos Központi Községi Nyomda.

- Galántai: A Habsburg-monarchia alkonya. Osztrák-magyar dualizmus 1867-1918. Budapest, 1985, Kossuth. 387 p. HU-ISBN 9630925893.

- HuszÁr Pál - VilsinszKy Károly: A pénzügyigazgatás kézikönyve. Budapest, 1911, Atheneum. 41 p.

OLÁH Ödön (szerk.): Tanulmányjelentés az Ausztriában és BoszniaHercegovinában fennálló határörizeti és állat-csempészet elleni intézkedésekröl. Budapest, 1912, Állami Nyomda.

- O'sváth Pál: Közbiztonságunk múltja és pandúrkorom emlékei. Budapest, 1905, O’svÁth Pál. 155 p.

PARÁDI: A határszéli csendőrség 1891-1914. Budapest, 1984, Határőrség. 91 p. HU-ISBN -

PARÁDI József et al. (szerk.): A magyar rendvédelem története. Budapest, $1996^{2}$, Osiris. 367 p. HU-ISBN 9630479583.

PARÁDI József: Pénzügyörség és vámhivatalok a határörizetben. Budapest, 2003, Tipico Design. 219 p. HU-ISBN 963762330 2./Rendvédelem a határokon a XIX-XX. században, 1./ HU-ISSN -

PARÁDI József: Rendörség a határörizetben. Budapest, 2003, Tipico Design. 266 p. HU-ISBN 963762332 9. /Rendvédelem a határokon a XIX-XX. században, 3./ HU-ISSN -

PONGRÁcz Emil — LuKÁCs Béla: A Magyar Királyi Pénzügyminisztérium ötévi müködése 1867-1871. Budapest, 1873, Pallas.

- Preszly Lóránd: A Magyar Királyi Csendörség története. 1881-1919. Budapest, 1920, Honvédelmi Sajtóvállalat. 142 p.

REKTOR Béla: A Magyar Királyi Csendörség oknyomozó története. Cleveland, Ohio, USA, 1980, Árpád Könyvkiadó Vállalat. 552 p. USA-ISBN 0 934214018

- Tisza Miksa: Magyarország rendörségeinek története a legrégibb időktől 1912-ig. Igló, 1913, Szepesi Lapok Nyomda. 327 p.

VÉCSEY Leo: A 40 éves budapesti detektív testület. Budapest, 1927, A Magyar Királyi Államrendőrség Detektívtestületének Nyugdíjpótló és Segélyező Egyesülete.

- Wittingheit Emil: A Magyar Királyi Pénzügyminisztérium tízévi müködése 1895-1905. Budapest, 1906, Steaphaneum.

- DEÁK Ágnes: Egy régi politikai rendszerváltás és az államrendőrség. Történelmi Szemle, L.évf. (2007) 3.sz. 351-372.p. HU-ISSN 0040-9634.

DEÁK Ágnes: Államrendőrségi információs hálózat Magyarországon 1849-1867. 81-92.p. In CsóKA Ferenc (szerk.): Szakszolgálat Magyarországon, avagy tanulmányok a hirszerzés és titkos adatgyüjtés világából 1780-2011. Budapest, 2012, Nemzetbiztonsági Szakszolgálat. 497 p. HU-ISBN 9789630832113.

Lugosi József: A rendvédelmi testületek fegyverei 1867-1918. Rendvédelem-történeti Füzetek (Acta Historiae Preasidii Ordinis), III.évf. (1993) 4.sz. 152-160.p. HU-ISSN 1216-6774. A tanulmány korábbi változata1992. szeptember 29-én, Budapesten hangzott el a Szemere Bertalan Magyar Rendvédelem-történeti Tudományos Társaság által szervezett rendvédelem-történeti tudományos konferenciasorozatnak ,.A dualista Magyarország rendvédelme. " címü IV. konferenciáján. A publikált tanulmány az előadás javított, bővített és átdolgozott változata. 
MEZEY

NAGY

OLASZ — PARÁDI - ZEIDLER: A magyar rendvédelmi testületek rendfokozati rendszere a kiegyezéstől az ezredfordulóig.

ÖRY

PARÁDI: A polgári magyar állam első határőrizeti szakszerve a Magyar Királyi Határrendőrség 1906-1914.

PARÁDI: A Magyar Királyi Csendőrség határörizeti feladatai 1891-1914.

PARÁDI: A Magyar Királyi Pénzügyminisztérium határörizeti feladatai az Osztrák-Magyar Monarchia magyarországi vámhatárain 1867-1914.

PARÁDI: A polgári magyar állam első központosított közbiztonsági szerve a Magyar Királyi Csendőrség.

PARÁDI: A dualizmus közrendvédelmi szerveinek jellemzői és tevékenységük tapasztalatai.

PARÁDI: A Magyar Királyi Határrendőrség a magyar határőrizet szakmai vezető testülete.

PARÁDI: A Magyar Királyi Csendőrség megalakulása és müködése 1881-1918.
MEZEY Barna: A kivételes hatalom. Rendvédelem-történeti Füzetek (Acta Historiae Preasidii Ordinis), IV.évf. (1994) 5.sz. 4-6.p. HU-ISSN 12166774. A tanulmány korábbi változata 1993. szeptember 21-én Budapesten hangzott el a Szemere Bertalan Magyar Rendvédelem-történeti Tudományos Társaság által szervezett rendvédelem-történeti tudományos konferenciasorozatnak a „Háború, forradalom, trianon” című V. konferenciáján. A publikált tanulmány az előadás javított, bővített és átdolgozott változata.

- Nagy László: A magyar Rendőrség-történeti Múzeum története. Rendvédelem-történeti Füzetek (Acta Historiae Preasidii Ordinis), XVII.évf. (2009) 20.sz. 79-92.p. HU-ISSN 1216-6774. A tanulmány korábbi változata 2006. szeptember 29-én, Budapesten hangzott el a Szemere Bertalan Magyar Rendvédelem-történeti Tudományos Társaság által szervezett rendvédelem-történeti tudományos konferenciasorozatnak „A XIX-XX. századi magyar forradalmak hatása a nemzeti rendvédelmi rendszerünkre." címü XX. konferenciáján. A publikált tanulmány az előadás javított, bővített és átdolgozott változata.

OlASz György — PARÁd József — ZEIDLER Sándor: A magyar rendvédelmi testületek rendfokozati rendszere a kiegyezéstöl az ezredfordulóig. Rendvédelem-történeti Füzetek (Acta Historiae Preasidii Ordinis), HU-ISSN 1216-6774. XV.évf. (2008) 18.sz. 28-63.p. HU-ISSN A tanulmány korábbi változata 2004. október 13-án Budapesten hangzott el a Szemere Bertalan Magyar Rendvédelem-történeti Tudományos Társaság által szervezett rendvédelem-történeti tudományos konferenciasorozatnak a „Karhatalmi feladatok a bünmegelözés és a békefenntartás szolgálatában Európában a XIX-XX. században” címü XVIII. konferenciáján. A publikált tanulmány az előadás javított, bővített és átdolgozott változata.

- ÖRY Károly: A Maréchaussée-tól a Gendarmerie Nationale-ig a Francia Csendörség történeti elözményei. Rendvédelem-történeti Füzetek (Acta Historiae Preasidii Ordinis), VII. évf. (1997) 8. sz. 75-77.p. HU-ISSN 12166774. A tanulmány korábbi változata 1996. október 29.-én Budapesten hangzott el a Szemere Bertalan Magyar Rendvédelem-történeti Tudományos Társaság által szervezett rendvédelem-történeti tudományos konferenciasorozatnak „A napóleoni közbiztonsági örtestület útja Párizstól - Itálián és Ausztrián keresztül - Budapestig" címü VIII. konferenciáján. A publikált tanulmány az előadás javított, bővített és átdolgozott változata.

PARÁDI József: A polgári magyar állam első határőrizeti szakszerve a Magyar Királyi Határrendőrség 1906-1914. Hadtörténelmi Közlemények, CI. évf. (1986) 3. sz. 541-570. p. HU-ISSN 0017-6540.

PARÁDI József: A Magyar Királyi Csendőrség határőrizeti feladatai 1891-1914. Hadtörténelmi Közlemények, CIII.évf. (1988) 1.sz. 56-92.p. HU-ISSN 0017-6540.

PARÁDI József: A Magyar Királyi Pénzügyminisztérium határőrizeti feladatai az Osztrák-Magyar Monarchia magyarországi vámhatárain 1867-1914. Hadtörténelmi Közlemények, CIV.évf. (1989) 2.sz. 177-196.p. HU-ISSN 0017-6540.

PARÁDI József: A polgári magyar állam első központosított közbiztonsági szerve a Magyar Királyi Csendőrség. Belügyi Szemle, XXXVII.évf. (1989) 2.sz. 35-40. p. HU-ISSN 0133-6738.

PARÁDI József: A dualizmus közrendvédelmi szerveinek jellemzői és tevékenységük tapasztalatai. Rendvédelem-történeti Füzetek (Acta Historiae Preasidii Ordinis), II.évf. (1992) 3.sz. 21-28.p. HU-ISSN 1216-6774. A tanulmány korábbi változata 1991. november 19.-én Budapesten hangzott el a Szemere Bertalan Magyar Rendvédelem-történeti Tudományos Társaság által szervezett rendvédelem-történeti tudományos konferenciasorozatnak a „Tradíció és korszerüség” című III. konferenciáján. A publikált tanulmány az előadás javított, bővített és átdolgozott változata.

PARÁDI József: A Magyar Királyi Határrendőrség a magyar határőrizet szakmai vezető testülete. Rendvédelem-történeti Füzetek (Acta Historiae Preasidii Ordinis), III.évf. (1993) 4.sz. 21-50.p. HU-ISSN 1216-6774. A tanulmány korábbi változata1992. szeptember 29-én, Budapesten hangzott el a Szemere Bertalan Magyar Rendvédelem-történeti Tudományos Társaság által szervezett rendvédelem-történeti tudományos konferenciasorozatnak , $A$ dualista Magyarország rendvédelme." címü IV. konferenciáján. A publikált tanulmány az előadás javított, bővített és átdolgozott változata.

PARÁDI József: A Magyar Királyi Csendőrség megalakulása és működése 1881-1918. Rendvédelem-történeti Füzetek (Acta Historiae Praesidii Ordinis), VII. évf. (1997) 8.sz. 78-83.p. HU-ISSN 1216-6774. A tanulmány korábbi változata 1996. október 29-én Budapesten hangzott el a Szemere Bertalan Magyar Rendvédelem-történeti Tudományos Társaság által szerve- 
PARÁDI: A dualizmuskori magyar
pénzügyörség és vámhivatalok.

PARÁDI: Áttérés a háborús határőrizetre az első világháború előtt.

PARÁDI: A Magyar Királyság rendvédelme 1867-1919.

PARÁDI: Rendvédelem vagy rendészet.

PARÁDI: A történelmi Magyarország határőrizeti tapasztalatai.

PARÁDI: A csendőrtisztképzés és a fizetési osztályokba sorolt állam alkalmazottak szakvizsgarendszere.

PARÁDI József: A Magyar Királyi Határrendőrség.

PARÁDI: Rendvédelmünk képzési és képesítési rendszere 1867-1945.

PARÁDI József: A magyar határőrizet tere a kiegyezéstől a második világháborúig.

PARÁDI: Elpusztított emlékhelyek. zett rendvédelem-történeti tudományos konferenciasorozatnak. „A napóleoni közbiztonsági örtestület útja Párizstól — Itálián és Ausztrián keresztül-Budapestig" címü VIII. konferenciáján. A publikált tanulmány az előadás javított, bővített és átdolgozott változata.

PARÁDI József: A dualizmuskori magyar pénzügyőrség és vámhivatalok. Rendvédelem-történeti Füzetek (Acta Historiae Preasidii Ordinis), VIII.évf. (1998) 9.sz. 82-85.p. HU-ISSN 1216-6774. A tanulmány korábbi változata 1997. szeptember 23-án, Budapesten hangzott el a Szemere Bertalan Magyar Rendvédelem-történeti Tudományos Társaság által szervezett rendvédelemtörténeti tudományos konferenciasorozatnak „Gazdasági rendvédelmünk a $X I X-X X$. században. " címü IX. konferenciáján. A publikált tanulmány az elöadás javított, bővített és átdolgozott változata.

PARÁDI József: Áttérés a háborús határőrizetre az első világháború előttt. Rendvédelem-történeti Füzetek (Acta Historiae Preasidii Ordinis), IV.évf. (1994) 5.sz. 13-17.p. HU-ISSN 1216-6774. A tanulmány korábbi változata 1993. szeptember 21-én Budapesten hangzott el a Szemere Bertalan Magyar Rendvédelem-történeti Tudományos Társaság által szervezett rendvédelemtörténeti tudományos konferenciasorozatnak a „Háború, forradalom, trianon” címü V. konferenciáján. A publikált tanulmány az előadás javított, bővített és átdolgozott változata.

PARÁDI József: A Magyar Királyság rendvédelme 1867-1919. Rendvédelem-történeti Füzetek (Acta Historiea Preasidii Ordinis), X. évf. (1999) 10.sz. 98-147.p. HU-ISSN 1216-6774. A tanulmány korábbi változata 1998. szeptember 22.-én Budapesten hangzott el a Szemere Bertalan Magyar Rendvédelem-történeti Tudományos Társaság által szervezett rendvédelemtörténeti tudományos konferenciasorozatnak ,A nyugati rendvédelem hatása a XIX-XX. századi magyar rendvédelemre" címü XI. konferenciáján. A publikált tanulmány az előadás javított, bővített és átdolgozott változata.

PARÁDI József: Rendvédelem vagy rendészet. Rendészeti Szemle, XLIX. évf. (2001) 2. sz. 97-108. p. HU-ISSN 1789-4689.

PARÁDI József: A történelmi Magyarország határőrizeti tapasztalatai. 357388.p. In Mezey Barna (szerk.): Eckhart Ferenc emlékkönyv. Budapest, 2004, Gondolat Kiadó. HU-ISBN 963950086 0. /Jogtörténeti értekezések, 28./ HU-ISSN 0134-0026.

PARÁDI József: A csendőrtisztképzés és a fizetési osztályokba sorolt állam alkalmazottak szakvizsgarendszere. Rendvédelem-történeti Füzetek (Acta Historiae Praesidii Ordini), XIII. évf. (2007) 16.sz. 100-104.p. HU-ISSN 1216-6774. A tanulmány korábbi változata 2002. november 12-én hangzott el a Szemere Bertalan Magyar Rendvédelem-történeti Tudományos Társaság által szervezett rendvédelem-történeti tudományos konferenciasorozatnak „, $A$ rendvédelmi szakképzés története" címü XVI. konferenciáján. A publikált tanulmány az előadás javított, bővített és átdolgozott változata.

PARÁDI József: A Magyar Királyi Határrendőrség. Rendvédelem-történeti Füzetek (Acta Historiae Praesidii Ordinis), XII. évf. (2007) 15.sz. 139-159.p. HU-ISSN 1216-6774. A tanulmány korábbi változata 2004. áprilisában Budapesten hangzott el a Szemere Bertalan Magyar Rendvédelem-történeti Tudományos Társaság Rendőrség-történeti Szakosztálya által szervezett Szemere Beszélgetések szimpózionsorozat rendezvényén a Rendőrség Tudományos Tanácsának közremüködésével. A publikált tanulmány az előadás javított, bővített és átdolgozott változata.

PARÁDI József: Rendvédelmünk képzési és képesítési rendszere 18671945. Rendvédelem-történeti Füzetek (Acta Historiae Preasidii Ordinis), XIII.évf. (2007) 16.sz. 90-93.p. HU-ISSN 1216-6774. A tanulmány korábbi változata 2002. november 12-én Budapesten hangzott el a Szemere Bertalan Magyar Rendvédelem-történeti Tudományos Társaság által szervezett rendvédelem-történeti tudományos konferenciasorozatnak „A rendvédelmi szakképzés története" címü XVI. konferenciáján. A publikált tanulmány az elöadás javított, bővített és átdolgozott változata.

PARÁDI József: A magyar határőrizet tere a kiegyezéstől a második világháborúig. Rendvédelem-történeti Füzetek (Acta Historiae Praesidii Ordinis), XII. évf. (2007) 15.sz. 125-138.p. HU-ISSN 1216-6774. A tanulmány korábbi változata 2005. augusztus 27-én a szlovéniai Lendván hangzott el a Hajnal István kör által szervezett tudományos konferencián. A publikált tanulmány az előadás javított, bővített és átdolgozott változata.

PARÁDI József: Elpusztított emlékhelyek. Rendvédelem-történeti Hírlevél (Nuntiotones Historiae Preasidii Ordinis), XVII.évf. (2008) 29-30.sz. 96109.p. HU-ISSN 1785-3257. 
PARÁDI: Rendőrség a magyar határőrizetben.

PARÁDI: Tények és érzelmek egy hajdani magyar rendvédelmi testület története kapcsán.

PARÁDI: A Magyar Királyság határrendőrsége.

PARÁDI: A polgári magyar állam rendvédelmi testületeinek humán viszonyai 1867-1945.

PARÁd: A Magyar Királyi Csendőrség szolgálati tevékenységei.

PARÁDI: A Magyar Királyi Csendőrség _

SZAKÁlY: A Magyar Királyi Csendőrség, az első központosított magyar közbiztonsági őrtestület.

SzAKÁLY: A Magyar Királyi Csendőrszervezete. ség 1919-1941.

PARÁDI József: Rendőrség a magyar határőrizetben. Rendvédelem-történeti Füzetek (Acta Historiae Preasidii Ordinis), XV. évf. (2008) 18. sz. 88-97.p. HU-ISSN 1216-6774. A tanulmány korábbi változata 2004. október 13.-án Budapesten hangzott el, a Szemere Bertalan Magyar Rendvédelem-történeti Tudományos Társaság által szervezett rendvédelem-történeti tudományos konferenciasorozatnak „Karhatalmi feladatok a bünmegelözés és a békefenntartás szolgálatában Európában a XIX-XX. században” címü XVIII. konferenciáján. A publikált tanulmány az előadás javított, bővített és átdolgozott változata.

PARÁDI József: Tények és érzelmek egy hajdani magyar rendvédelmi testület története kapcsán. Rendvédelem-történeti Füzetek (Acta Historiae Preasidii Ordinis), XVII.évf. (2009) 20.sz. 93-99.p. HU-ISSN 1216-6774. A tanulmány korábbi változata 2006. szeptember 29-én Budapesten hangzott el a Szemere Bertalan Magyar Rendvédelem-történeti Tudományos Társaság által szervezett rendvédelem-történeti tudományos konferenciasorozatnak „,A XIX-XX. századi magyar forradalmak hatása a nemzeti rendvédelmi rendszerünkre” címü XX. konferenciáján. A publikált tanulmány az előadás javított, bővített és átdolgozott változata.

PARÁDI József: A Magyar Királyság határrendőrsége. Rendvédelemtörténeti Füzetek (Acta Historiae Preasidii Ordinis), XVIII. évf. (2010) 21. sz. 101-116.p. HU-ISSN 1216-6774. A tanulmány korábbi változata 2007. október 5.-én Budapesten hangzott el a Szemere Bertalan Magyar Rendvédelem-történeti Tudományos Társaság által szervezett rendvédelem-történeti tudományos konferenciasorozatnak ,A magyar rendvédelem fejlödése a XIX$X X$. században" című XXI. konferenciáján. A publikált tanulmány az előadás javított, bővített és átdolgozott változata.

PARÁDI József: A polgári magyar állam rendvédelmi testületeinek humán viszonyai 1867-1945. Rendvédelem-történeti Füzetek (Acta Historiae Preasidii Ordinis), XIX. évf. (2010) 22. sz. 92-114. p. HU-ISSN 1216-6774. A tanulmány korábbi változata 2008. október 10.-én Budapesten hangzott el, a Szemere Bertalan Magyar Rendvédelem-történeti Tudományos Társaság által szervezett rendvédelem-történeti tudományos konferenciasorozatnak „Másfél évszázad rendszerváltozásainak hatásai a nemzeti rendvédelmünkre" címü XXII. konferenciáján. A publikált tanulmány az előadás javított, bővített és átdolgozott változata.

PARÁDI József: A Magyar Királyi Csendőrség szolgálati tevékenységei. Rendvédelem-történeti Füzetek (Acta Historiae Preasidii Ordinis), XXI.évf. (2011) 24.sz. 90-99.p. HU-ISSN 1216-6774. A tanulmány korábbi változata 2009. december 3.-án, Budapesten hangzott el a Szemere Bertalan Magyar Rendvédelem-történeti Tudományos Társaság által szervezett rendvédelemtörténeti tudományos konferenciasorozatnak a „Csendörség AusztriaMagyarországon, illetve Ausztriában és Magyarországon 1849-2005. " címü XXIV. konferenciáján. A publikált tanulmány az előadás javított, bővített és átdolgozott változata.

PARÁDI József: A Magyar Királyi Csendőrség szervezete. Rendvédelemtörténeti Füzetek (Acta Historiae Preasidii Ordinis), XXI.évf. (2011) 24.sz. 80-90.p. HU-ISSN 1216-6774. A tanulmány korábbi változata 2009. december 3. Budapesten hangzott el, a Szemere Bertalan Magyar Rendvédelemtörténeti Tudományos Társaság által szervezett rendvédelem-történeti tudományos konferenciasorozatnak ,,Csendörség Ausztria-Magyarországon, illetve Ausztriában és Magyarországon 1849-2005" címü XXIV. konferenciáján. A publikált tanulmány az előadás javított, bővített és átdolgozott változata.

SZAKÁLY Sándor: A Magyar Királyi Csendőrség, az első központosított magyar közbiztonsági örtestület. Rendvédelem-történeti Füzetek (Acta Historiae Preasidii Ordinis), III. évf. (1993) 4.sz. 51-58.p. HU-ISSN 12166774. A tanulmány korábbi változata 1992. szeptember 29-én Budapesten hangzott el a Szemere Bertalan Magyar Rendvédelem-történeti Tudományos Társaság által szervezett rendvédelem-történeti tudományos konferenciasorozatnak a „Dualista Magyarország rendvédelme” címü IV. konferenciáján. A publikált tanulmány az előadás javított, bővített és átdolgozott változata.

SzAKÁLy Sándor: A Magyar Királyi Csendőrség 1919-1941. Rendvédelemtörténeti Füzetek (Acta Historiea Preasidii Ordinis), V. évf. (1995) 6. sz. 122-129. p. HU-ISSN 1216-6774. A tanulmány korábbi változata 1994 októberében Budapesten hangzott el a Szemere Bertalan Magyar Rendvédelemtörténeti Tudományos Társaság által szervezett rendvédelem-történeti tudományos konferenciasorozatnak „A két világháború közötti Magyar Királyság rendvédelme” címủ VI. konferenciáján. A publikált tanulmány az előadás javított, bővített és átdolgozott változata.

ZACHAR József: Fejezetek az osztrák csendőrség történetéből 1849-1918. Rendvédelem-történeti Füzetek (Acta Historiae Preasidii Ordinis), VII.évf. (1997) 8.sz. 105-109.p. HU-ISSN 1216-6774. A tanulmány korábbi változata 
ZEIDLER: A Magyar Királyi Csendőrség rendfokozati rendszere és jelvényei.

\section{CIKKEK}

PARÁDI: Pénzügyőrség és vámhivatalok a dualizmus korában. I.rész.

PARÁDI: Pénzügyőrség és vámhivatalok a dualizmus korában. I.rész.

\section{DOKUMENTUMGYÜJTEMÉNYEK}

MÁRFFY

THÚRÓCZY

\section{SEMATIZMUSOK}

Csendőrségi Lapok (szerk.): Zsebkönyv a Magyar Királyi Csendörség számára 1894.

Magyarország tiszti czím- és névtára 1870-1814. Vámhivatali fejezetek.

\section{KÉZIRATOK}

PARÁDI: A dualista Magyarország határörizete 1867-1914.

\section{JOGSZABÁLYOK}

1870/XLII.tc.

1871/XVIII.tc.

1872/XXXVI.tc.

1881/II.tc.

1881/III.tc.

1881/XXI.tc.

1882/X.tc.

1883/XXVII.tc.

1886/XXI.tc.

1888/XIV.tc.

1897/XXXIV.tc.

1903/VIII.tc.

1916/XXXVII.tc.

50 431/1891.BM.r.

5692/1905.ME.r.

91 000/1905.BM.kr.
1996. október 29-én, Budapesten hangzott el a Szemere Bertalan Magyar Rendvédelem-történeti Tudományos Társaság által szervezett rendvédelemtörténeti tudományos konferenciasorozatnak , A napóleoni közbiztonsági örtestület útja Párizstól — Itálián és Ausztrián keresztül — Budapestig. ” címü VIII. konferenciáján. A publikált tanulmány az előadás javított, bővített és átdolgozott változata.

ZEIDLER Sándor: A Magyar Királyi Csendőrség rendfokozati rendszere és jelvényei. Rendvédelem-történeti Füzetek (Acta Historiae Preasidii Ordinis), VII.évf. (1997) 8.sz. 110-112.p. HU-ISSN 1216-6774. A tanulmány korábbi változata 1996. október 29-én Budapesten hangzott el a Szemere Bertalan Magyar Rendvédelem-történeti Tudományos Társaság által szervezett rendvédelem-történeti tudományos konferenciasorozatnak „A napóleoni közbiztonsági örtestület útja Párizstól - Itálián és Ausztrián keresztül - Budapestig" címü VIII. konferenciáján. A publikált tanulmány az előadás javított, bővített és átdolgozott változata.

PARÁDI József: Pénzügyőrség és vámhivatalok a dualizmus korában. I.rész. Pénzügyőrök Lapja, XXXIV.évf. (1983) 9-10.sz. 12-13.p. HU-ISSN 0133-2872.

PARÁDI József: Pénzügyőrség és vámhivatalok a dualizmus korában. II.rész. Pénzügyőrök Lapja, XXXIV.évf. (1983) 11.sz. 8-9.p. HU-ISSN 0133-2872.

- MÁRFFy Ede (szerk.): A magyar határvámigazgatás és vámkezelés szabályai. Budapest, 1910, Atheneum.

- ThúRóczy Adolf (szerk.): A Magyar Korona területén érvényes határvámtörvények és szabályok. Budapest, 1896,Franklin.

Csendőrségi Lapok (szerk.): Zsebkönyv a Magyar Királyi Csendőrség számára 1894. Budapest, 1894, Franklin. VIII.évf.

Magyarország tiszti czím- és névtára 1870-1814. Vámhivatali fejezetek.

PARÁDI József: A dualista Magyarország határőrizete 1867-1914. 40-45.p. Bölcsészdoktori disszertáció (ELTE BTK). Kézirat. Budapest, 1985.

— 1870/XLII.tc. a köztörvényhatóságok rendezéséröl.

- 1871/XVIII.tc. a községek rendezéséröl.

— 1872/XXXVI.tc. Buda-Pest fővárosi törvényhatóság alakításáról és rendezéséről.

— 1881/II.tc. a csendőrség legénységi állományának a kiegészítéséröl.

- 1881/III.tc. a közbiztonsági szolgálat szervezéséröl.

— 1881/XXI.tc. a Budapest-fővárosi rendőrségről.

- 1882/X.tc. a Magyar Királyi Csendőrség által, a törvényhatósági joggal felruházott városok kül- és belterületein való teljesítendőkről.

- 1883/XXVII.tc. az V. és VI. csendőrparancsnokságok felállítása céljából a csendőrség legénységi állományának ideiglenes kiegészítése tárgyában.

1886/XXI.tc. a köztörvényhatóságokról.

- 1888/XIV.tc. az Osztrák-Magyar Monarchiának Romániával, a Monarchia két állama és Románia közt fennforgott határvillongások kiegyenlítése végett, a határvonal újabb megállapítása és azzal kapcsolatos kérdések szabályozása tárgyában kötött, s Bukarestben 1887. évi december 7-én november 25-én aláírt nemzetközi egyezmény beczikkelyezéséről.

1897/XXXIV.tc. a bünvádi perrendtartás életbe léptetéséről.

1903/VIII.tc. a határrendőrségről.

1916/XXXVII.tc. a fiumei m. kir. állami rendőrségről.

- $\quad 50$ 341/1891.BM.r. az 1881/XIV.tc-vel beczikkelyezett magyar-román határegyezmény alapján kiadott határőrizeti utasítás tárgyában.

Magyarországi Rendeletek Tára, XXV.évf. (1891) I. füzet. 877-879.p.

5692/1905.ME.r. a határrendőrségről szóló 1903/VIII. tc. életbeléptetéséről.

Magyarországi Rendeletek Tára, XXXIX.évf. (1905) XII.füzet. 1455.p.

91 000/1905.BM.kr. a határrendőrségről szóló 1903/VIII.tc. életbe léptetésének a végrehajtásáról.

Magyarországi Rendeletek Tára, XXXIX.évf. (1905) XII.füzet. 1455-1541.p. 


\section{300/1908.IM.r.}

153 358/1913.BM.r.

\section{Mellékletek jegyzéke:}

\section{I.sz.melléklet}

A dualizmuskori magyar rendvédelmi testületek.

II.sz.melléklet

A fővárosi rendőrtisztviselők fizetési osztályai.

III.sz.melléklet

A Magyar Királyi Vámhivatalok.

IV.sz.melléklet

A Magyar Királyi Határrendőrség belső szolgálati kapcsolatai.

V.sz.melléklet

A Magyar Királyi Határrendőrség szervezete.

A dualizmuskori magyar rendvédelmi testületek.

\begin{tabular}{|c|c|c|}
\hline Testület & Létszám & \% -os arány \\
\hline Állami és önkormányzati rendőrségek hozzávetőlegesen & 12000 fó & $36,60 \%$ \\
\hline Magyar Királyi Csendőrség & 12000 fö & $36,60 \%$ \\
\hline Büntetés-végrehajtás & 3000 fö & $9,15 \%$ \\
\hline Magyar Királyi Pénzügyőrség & 5500 fö & $16,77 \%$ \\
\hline Magyar Királyi Testőrségek & 142 fö & $0,44 \%$ \\
\hline Magyar Királyi Koronaőrség & 58 fö & $0,19 \%$ \\
\hline Képviselőházi őrség & 78 fö & $0,25 \%$ \\
\hline Mindösszesen: & 33678 fö & $100 \%$ \\
\hline
\end{tabular}

ForRÁs ! PARÁd József et. al. (szerk.): A magyar rendvédelem története. 283.p. Budapest, 1996², Osiris. 367 p. HU-ISBN 963047958 3. 283.p.

A fövárosi rendörtisztviselök fizetési osztályai.

II.sz.melléklet

\begin{tabular}{|c|c|c|c|c|c|}
\hline \multicolumn{3}{|c|}{$\begin{array}{l}\text { Fizetési } \\
\text { osztály fokozat összeg }\end{array}$} & Fogalmazó & $\begin{array}{l}\text { Rendőr } \\
\text { Felügyelő }\end{array}$ & Detektív \\
\hline I. & & 2785 & & & \\
\hline II. & & 1857 & & & \\
\hline III. & & 1308 & & & \\
\hline IV. & $\begin{array}{l}1 . \\
2 .\end{array}$ & $\begin{array}{c}1054 \\
956\end{array}$ & r.fökapitány & & \\
\hline $\mathrm{V}$. & $\begin{array}{l}1 . \\
2 .\end{array}$ & $\begin{array}{c}804.50 \\
707 \\
\end{array}$ & r. fökapitány h. & r. föparancsnok & \\
\hline VI. & $\begin{array}{l}1 . \\
2 . \\
3 .\end{array}$ & $\begin{array}{c}615.50 \\
556.50 \\
499 \\
\end{array}$ & r. fótanácsos & r. felügyelö & \\
\hline VII. & $\begin{array}{l}1 . \\
2 . \\
3 .\end{array}$ & $\begin{array}{l}443.50 \\
404.50 \\
365.50\end{array}$ & r. tanácsos & r. felügyelö & $\begin{array}{l}\text { detektív - } \\
\text { föfelügyelö }\end{array}$ \\
\hline VIII. & $\begin{array}{l}1 . \\
2 . \\
3 .\end{array}$ & $\begin{array}{c}327.50 \\
305 \\
288 \\
\end{array}$ & r. kapitány & r. felügyelö & $\begin{array}{l}\text { detektív - } \\
\text { felügyelő }\end{array}$ \\
\hline IX. & $\begin{array}{l}1 . \\
2 . \\
3 .\end{array}$ & $\begin{array}{c}260.50 \\
243 \\
226\end{array}$ & r. fogalmazó & r. felügyelö & detektív \\
\hline $\mathrm{X}$. & $\begin{array}{l}1 . \\
2 . \\
3 .\end{array}$ & $\begin{array}{c}215 \\
203.50 \\
192.50 \\
\end{array}$ & r. segédfogalmazó & r. felügyelö & detektív \\
\hline XI. & $\begin{array}{l}1 . \\
2 . \\
3 .\end{array}$ & $\begin{array}{l}181 \\
172 \\
163 \\
\end{array}$ & & & \\
\hline Gy. & $\begin{array}{l}\mathrm{D} \\
\mathrm{E}\end{array}$ & $\begin{array}{l}146 \\
129 \\
\end{array}$ & r.fogalmazógyakornok & r.felügyelőgyakornok & detektívgyakornok \\
\hline
\end{tabular}

Jelmagyarázat: Gy - gyakornok, D - főiskolai vagy egyetemi diplomával rendelkező $\mathbf{E}$ - érettségizett

ForRás!PARÁdI József et. al. (szerk.): A magyar rendvédelem története. 320.p. Budapest, 1996², Osiris. 367 p. HU-ISBN 963 04 7958 3. $283 . p$. 


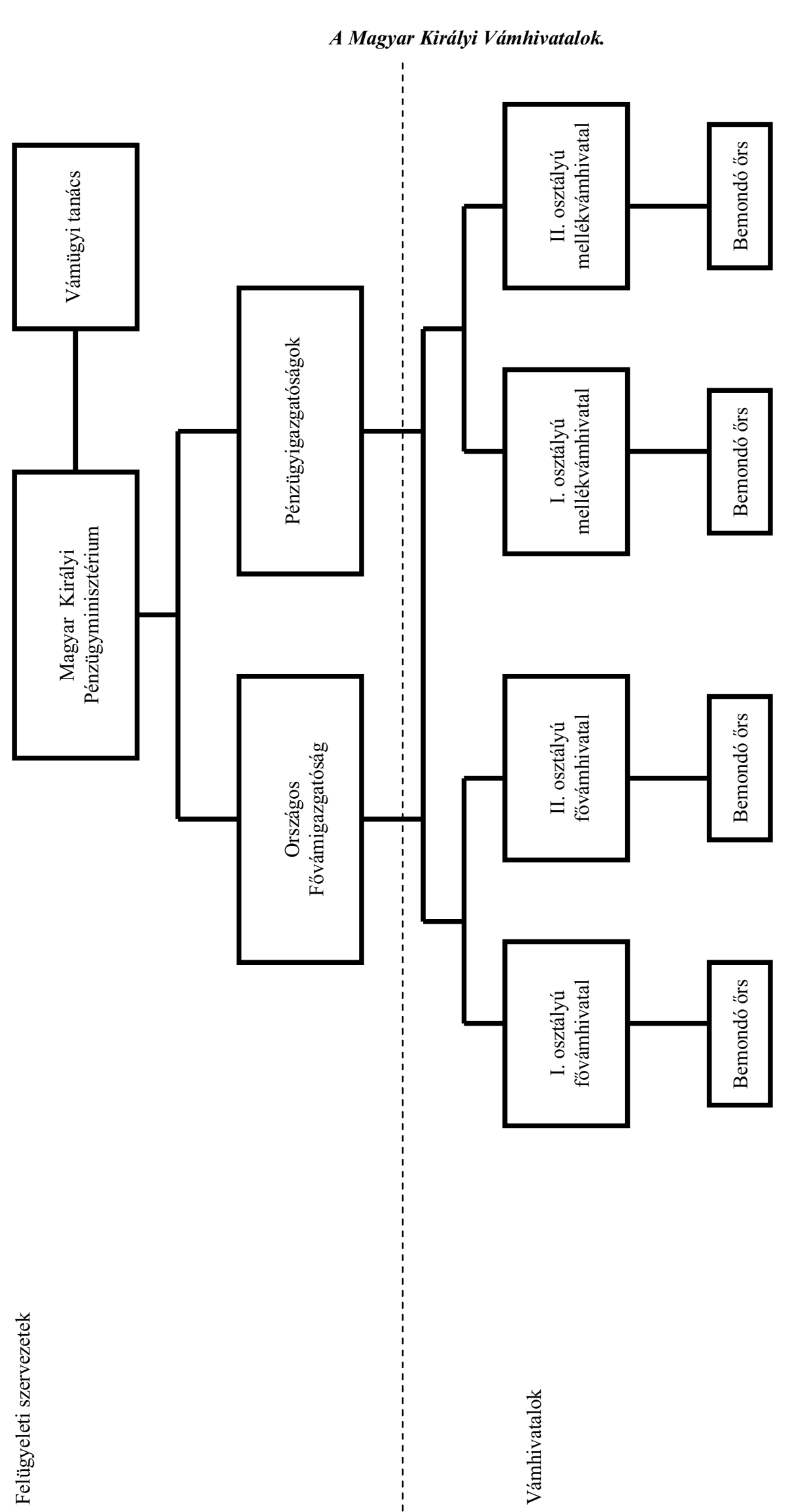

ForRás ! PARÁDI József et. al. (szerk.): A magyar rendvédelem története. 282.p. Budapest, $1996^{2}$, Osiris. 367 p. HU-ISBN 963047958 3. 283.p. 
A Magyar Királyi Határrendörség belsö szolgálati kapcsolatai.

IV.sz. melléklet

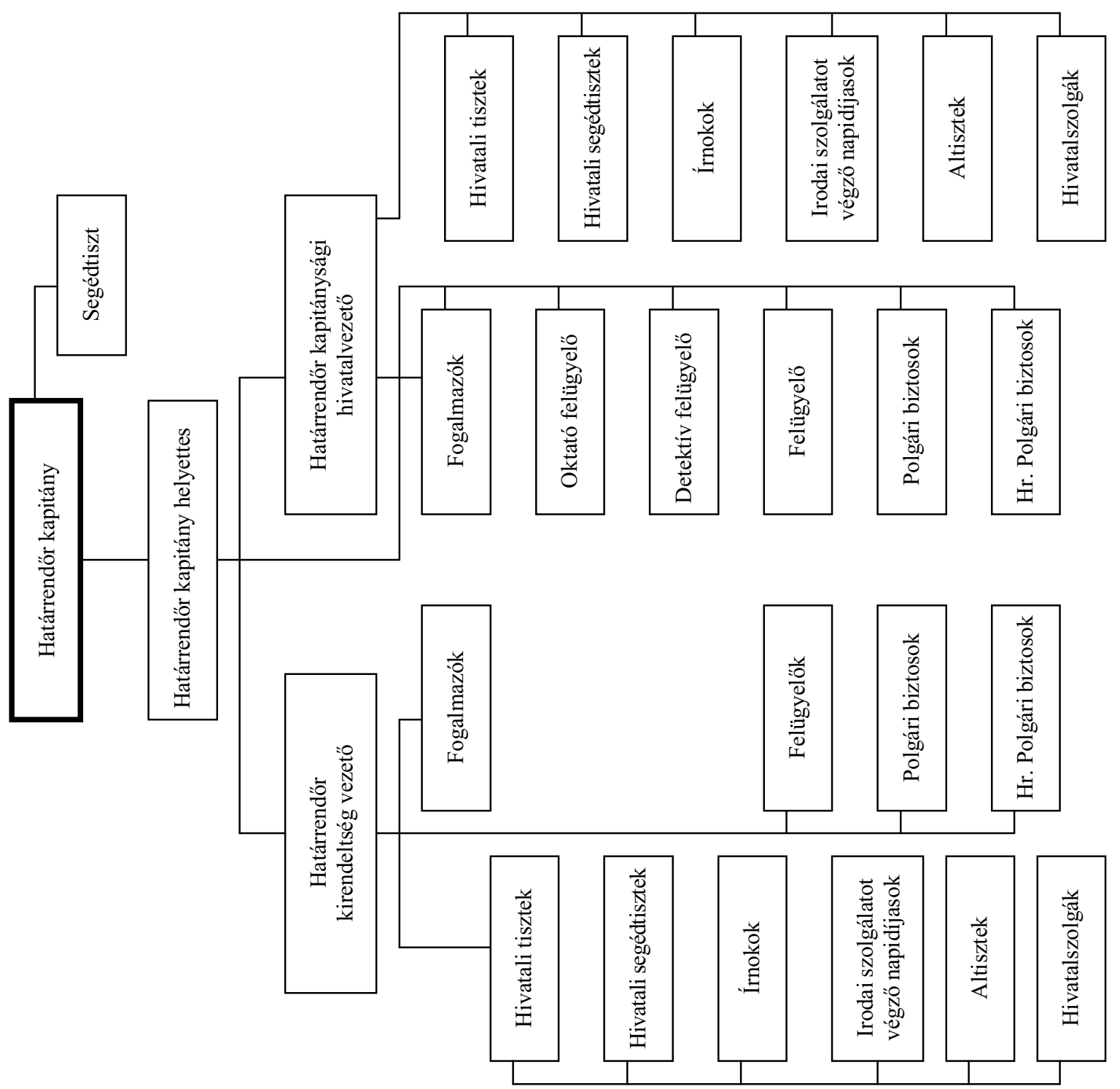

ForRás ! PARÁDI József: Rendörség a határörizetben. 258.p. Budapest, 2003, Tipico Design. 266 p. HU-ISBN 963762332 9. /Rendvédelem a határokon a XIX-XX. században, 3./ HU-ISSN -

\section{A Magyar Királyi Határrendörség szervezete.}

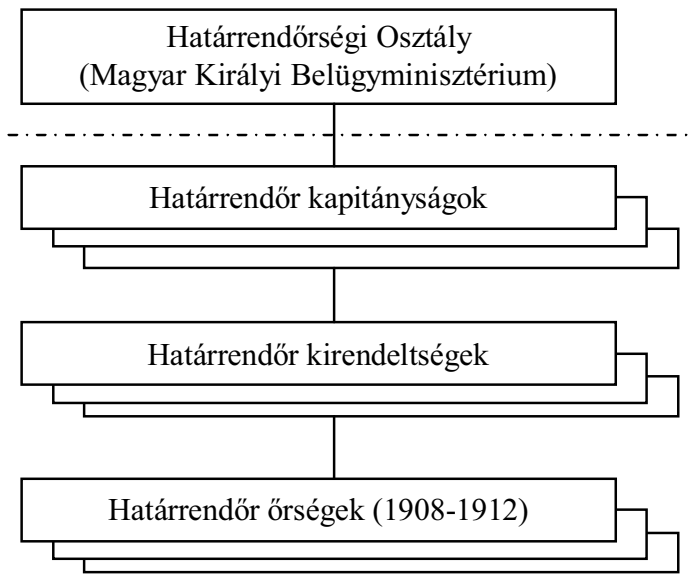

ForRás! PARÁDI József: Rendörség a határőrizetben. 253.p. Budapest, 2003, Tipico Design. 266 p. HU-ISBN 963762332 9. /Rendvédelem a határokon a XIX-XX. században, 3./ HU-ISSN - 